\title{
Toward the efficient use of Beauveria bassiana in integrated cotton insect pest management
}

\author{
DANNON H. Fabrice ${ }^{1,2^{*}}$ (D, DANNON A. Elie ${ }^{2,3}$, DOURO-KPINDOU O. Kobi ${ }^{2}$, ZINSOU A. Valerien?', \\ HOUNDETE A. Thomas ${ }^{4}$, TOFFA-MEHINTO Joëlle ${ }^{5}$, ELEGBEDE I. A. T. Maurille', OLOU B. Dénis ${ }^{6}$ and TAMÒ Manuele ${ }^{2}$
}

\begin{abstract}
Background: For controlling the resistance to insects, in particular carpophagous and phyllophagous caterpillars, using chemical pesticides has led to contamination of cotton area in Benin. Facing this problem, alternative methods including the use of entomopathogenic fungi as biopesticide could be a sound measure to preserve the environment, biodiversity and ensure good quality of crops. Previous studies have revealed the insecticidal potential of the entomopathogenic Beauveria bassiana on some insect pest species. However, little is known about its effectiveness on cotton Lepidopteran pests. This review is done to learn more about $B$. bassina for its application in controlling cotton insect pests, especially Lepidopteran species.
\end{abstract}

Main body: Different sections of the current review deal with the related description and action modes of $B$. bassiana against insects, multi-trophic interactions between B. bassiana and plants, arthropods, soil and other microbes, and biological control programs including B. bassiana during last decade. Advantages and constraints in applying B. bassiana and challenges in commercialization of B. bassiana-based biopesticide have been addressed. In this review, emphasis is put on the application methods and targeted insects in various studies with regard to their applicability in cotton.

Conclusion: This review helps us to identify the knowledge gaps related to application of B. bassiana on cotton pest in general and especially in Lepidopteran species in Benin. This work should be supported by complementary laboratory bioassays, station and/or fields experiments for effective management of cotton Lepidopteran pests in Benin.

Keywords: Biopesticide, Entomopathogenic fungus, Beauveria bassiana, Action modes, Pest management, Cotton

\section{Background}

The hopeful perspective projected for crop protection and public health as a result of the introduction of chemical pesticides is now open to serious question because of an alarming increase of resistance occurring in insects, pathogens, vertebrates, and a lesser extent in

\footnotetext{
* Correspondence: icedannon@gmail.com

'Laboratory of Phytotechnic, Improvement and Protection of Plants, Faculty of Agronomy, University of Parakou, BP 123, Parakou, Benin

${ }^{2}$ International Institute of Tropical Agriculture, 08 BP 0932 Tri Postal, Cotonou, Benin

Full list of author information is available at the end of the article
}

weeds (National Research Council [NRC] 1986). In the case of insect pests, one of the practices inducing selection of resistant crop populations is due to an overuse of same or closely related chemical insecticides (Food and Agriculture Organization [FAO] 2012). Facing this challenge, integrated pest management (IPM) options become attractive and environmentally friendly for crops protection against insect pests. Of these, biological control focusing on the use of natural enemies of insects, especially on entomopathogenic fungus, remains a interesting alternative tactic in the framework of pest status changing (Sewify et al. 2009). Of particular

(c) The Author(s). 2020 Open Access This article is licensed under a Creative Commons Attribution 4.0 International License, which permits use, sharing, adaptation, distribution and reproduction in any medium or format, as long as you give appropriate credit to the original author(s) and the source, provide a link to the Creative Commons licence, and indicate if changes were made. The images or other third party material in this article are included in the article's Creative Commons licence, unless indicated otherwise in a credit line to the material. If material is not included in the article's Creative Commons licence and your intended use is not permitted by statutory regulation or exceeds the permitted use, you will need to obtain permission directly from the copyright holder. To view a copy of this licence, visit http://creativecommons.org/licenses/by/4.0/ 
interest is the ability displayed by various genera of entomopathogenic fungi to colonize wide plant species in different families, both naturally and artificially following inoculation, ensuring protection against not only insect pests but also plant pathogens (Jaber and Ownley 2018).

Several studies suggest that fungus Beauveria bassiana is a promising agent for use as bio-insecticide to control various pest targets. This article reviews the currently available literatures on the description of $B$. bassiana and its modes of action against insects, describes the multi-trophic interactions between $B$. bassiana and plants, arthropods, soil, and other microbes. It also reviews biological control programs including $B$. bassiana for crop protection from 2009 to 2019.

This review analytically synthetizes the studies on crop pest management using $B$. Bassiana for its possible application in cotton insect pest management.

\section{Synthesis methodology}

The literatures searching strategy adopted in the current review was mainly based on the use of databases engines Google Scholar and CABI Direct. Various key words were used, namely "Beauveria" and "pest" and "biological control". There were about 17000 results on Google Scholar including all languages. The 30 most relevant articles were retained for review. With CABI Direct search, there were 1994 results (approx.) for all fields over the period of 2009 to 2019. The 22 most relevant articles were retained for review. In sum, 110 documents including articles (99), book chapters (4), theses (3), research memory (1) and research reports (3) were used to carry out the present bibliographic synthesis.

\section{B. bassiana (Balsamo) Vuillemin: a biological control agent}

Description of the fungus B. bassiana: history, taxonomy and morphology

\section{History}

In 1835, the entomologist BASSI Agostino of Lodi, discovered the causal agent of pebrine disease that turned legions of Italy's silkworms into white mummies (Lord 2005). The characteristic appearance of cadavers covered with a white powdery layer gave rise to the descriptor, "white muscardine disease". Later, BEAUVERIE Jean described this pathogen as Botrytis bassiana (De Kouassi 2001). The genus Beauveria was formal only around the twentieth century when Vuillemin (1912) claimed that Botrytis bassiana (Bals.-Criv) was a species that belongs to the genus Beauveria (Halouane 2008).

The classification of hyphomycetes and especial species of the genus Beauveria has been subjected to several revisions because of the increasing taxonomic complexity of Beauveria. The main characteristic of hyphomycetes (Deuteromycotina) is that they lack sexual reproduction, making the taxonomists consider only morpho-ontogenic characteristics to discriminate between species (De Kouassi 2001). Moreover, there was an increasing in taxonomic complexity of Beauveria. Subsequently, the entomopathogenic hyphomycetes consisted of more than twenty genera including Beauveria (Sung et al. 2001) which were thought to belong to Clavicipitaceae family and were potentially related to the genus Cordyceps (Humber 2000). Despite its cosmopolitan distribution and long history in mycology, the teleomorphic state of B. bassiana was not clear. However, Schaerffenberg (1955) cited by Sung et al. (2006) reported the teleomorphic Clavicipitaceae of $B$. bassiana, but with little evidence. A new species Cordyceps bassiana has been described from China on a carpenterworm larva, Prionoxystus robiniae (Lepidoptera: Cossidae), and probably related to B. bassiana (Li et al. 2001). Later, Sung et al. (2006) not only provided an additional insight into the systematics of Cordyceps, but also confirmed the anamorph feature of $B$. bassiana when culturing the fungus with artificial diet.

\section{Taxonomy of B. bassiana}

The complete systematic position of B. bassiana according to Sung et al. (2006) and Halouane (2008) is as follows:

- Kingdom: Fungi,

- Phylum: Ascomycota,

- Class: Sordariomycetes,

- Order: Hypocreales,

- Family: Clavicipitaceae / Cordicipitaceae or ophiocordicipitaceae

- Genus: Beauveria,

- Species: B. bassiana (Bals.-Criv.) (Vuil., 1912).

In some documents, the pathogen was considered to belong to Cordycipitaceae (Vigneshwaran 2015) or Ophiocordicipitaceae (Sensagent 2000-2016).

\section{Morphology of B. bassiana}

The fungus B. bassiana (Bals.) Vuill. was of terrigenous origin, saprophyte ubiquitous and pathogen for many insect orders such as: Lepidoptera, Hemiptera, Coleoptera, Hymenoptera, Homoptera, Hemiptera and Orthoptera (Sabbahi 2008; Li et al. 2001). The asexual spores of $B$. bassaina are conidia of white to yellowish color bearing by long zigzag transparent and septal filaments. Hyphae diameter varies between $2.5 \mu \mathrm{m}$ and $25 \mu \mathrm{m}$.

Different types of conidia can be produced by $B$. bassiana depending on the environment. In the presence of air (aerobic environment), the fungus produces spherical 
$(1-4 \mu \mathrm{m}$ in diameter) or oval $(1.55-5.5 \mu \mathrm{m} \times 1-3 \mu \mathrm{m}$ in size) conidia but in an anaerobic condition, it produces oval shape blastospores $(2-3 \mu \mathrm{m}$ in diameter and $7 \mu \mathrm{m}$ in length). Blastospores and conidia are all infectious organs (Weiser 1972; Lipa 1975; Sabbahi 2008).

\section{Mode of action of $B$. bassiana against insects}

The infection cycle of $B$. bassiana in invertebrates bodies has been depicted by Mascarin and Jaronski (2016).

Asexual spores (conidia) are dispersed by wind, rain splashing or even by arthropod vectors facilitating the fungus to establish infection on susceptible hosts (OrtizUrquiza and Keyhani 2013).

The host infection by the fungus occurs in four steps: adhesion, germination and differentiation, penetration, and dissemination.

\section{$1^{\text {st }}$ step: adhesion.}

It is characterized by recognition and compatibility mechanisms of conidia of the host cuticle cells (Vey et al. 1982 reported by De Kouassi 2001). Conidia (or in some cases blastospores) were attached to insect's cuticle by electrostatic and chemical forces (Mascarin and Jaronski 2016). Then, through the production of mucilage, they induced epicuticular modification (Wraight and Roberts 1987) leading to conidia germination.

\section{$2^{\text {nd }}$ step: germination-differentiation.}

Germination is a process that depends on environmental conditions, host physiology (biochemical composition of the host cuticle) as well. Such conditions can stimulate or inhibit it (Butt et al. 1995; Butt and Beckett 1994; Smith and Grula 1982; St Leger et al. 1989b). When conditions are suitable, conidia or blastospores germination leads to germ tubes formation. In fact, conidia germinate and form a germ tub with rehydration and chemical stimuli (Mascarin and Jaronski 2016).

Differentiation is characterized by the appressoria or penetration peg establishment, which serves as inking point, softening the cuticle and promoting penetration. For this purpose, the germ tub may form a specialized structure, namely appressorium (i.e., an enlarged cell expression bearing key hydrolytic cuticle-degrading enzymes) or penetration peg enabling hyphae growth to breach the host integument (De Kouassi 2001; Mascarin and Jaronski 2016).

However, appressoria production is highly dependent on nutritional value of the host cuticle (Magalhaes et al. 1988; St Leger et al. 1989a). A nutritious cuticle may stimulate mycelial growth rather than penetration (St Leger et al. 1989a).

\section{$3^{\text {rd }}$ step: penetration.}

From the appressorium or penetration peg and with the hydrolytic action of enzymes (proteases, chitinases, lipases: the most important being proteases), mechanical pressure, and other factors (such as oxalate), the fungus is able to penetrate all cuticle layers until reaching a nutrient-rich environment, i.e. the insect hemolymph.

$4^{\text {th }}$ step: dissemination within the host and to another host. In the hemolymph, the fungus undergoes a morphogenetic differentiation from filamentous growth to single-celled, yeast-like hyphal bodies or blastospores that strategically exploit nutrients, colonize internal tissues, and disturb the host immune system. During this stage of the infection, the fungus can also secrete toxic metabolites that help to overcome the insect's immune defense mechanisms for successfully colonization. Some strains produce non-enzymatic toxins such as beauvericin, beauverolides, bassianolides, and isarolides increasing the speed of the infection process (Hajeck and StLeger 1994; Roberts 1981). These events eventually lead to the death of host that became mummified.

When the infected insect dies, the fungus produces an antibiotic called "Oosporin" that is used to overcome bacteria competition in insect gut (De Kouassi 2001). Then, B. bassiana hyphae cross the insect integument preferentially at the inter-segmental level and then become cottony white. Finally, conidiophores appear on the mummified cadavers after a few days and bear newly infection conidia (sporulation) for dispersal (passive dissemination).

\section{Multi-trophic interactions between B. Bassiana and plants, arthropods, soil and other microbes}

Mascarin and Jaronski (2016) depicted a conceptual summary of the multi-trophic interactions between $B$. bassiana and plants, arthropods, soils and other microbes in a landscape community scenario.

According to these scientists, a saprophytic life story occurs in the soil with conidia shifting in mycelium, whereas the ability of this fungus to form sclerotium remains unknown, as this propagule has been observed neither under in vitro nor under natural conditions; the fungus can also infect soil-inhabiting insects and may transfer nitrogen from the insect to the plant through establishment of root endophyte colonization.

Endophytisme of $B$. Bassiana is the fungus life mode within the plant. For this purpose, B. Bassiana colonizes the roots and aerial organs such as: stems, leaves and seeds without causing damage to the plant. Then, insects feeding on these plant organs may get contaminated and then infected by fungal spores. Dead insects may sporulate, becoming a new contamination source through their sporulated cadavers, aerogenic spores or perhaps endophytic colonization for other organisms including 
predators and parasitoids. Such organisms may interact with the fungus in transmitting its spores (vectors). Interactions should be more complex. Therefore, damage from insect pests would be controlled in plant with the endophytic colonization by the fungus that triggers systemic resistance defenses or by direct antagonism through antibiosis or nutrient competition.

The teleomorph trait of the fungus has been reported to be related to Cordyceps sp. (Li et al. 2001) and appears to be only found in Asia where it is commonly used in Chinese medicine (Mascarin and Jaronski 2016).

\section{Success history of $B$. bassiana application in insect pests' management}

Synthesis of control programs including B. bassiana application for crop protection

Several studies revealed the insecticidal potential of $B$. bassiana as mycopesticides and commercial endophytic fungi (Jaber and Ownley 2018). All the studies involved direct application of the entomopathogen to target pests or indirect application by inoculation of the pest host plant. In the last case, B. bassiana is considered as an endophyte of the host plant. In the endophytic colonization strategy, methods of inoculating plant species consists of seed coating and seedlings injection (Brownbridge et al. 2012), immersion of radicles, roots or rhizomes (Posada and Vega 2005, 2006), stem injection (Posada et al. 2007; Tefera and Vidal 2009), soil drenching (Posada et al. 2007) and foliar spraying (Gurulingappa et al. 2010; Posada et al. 2007). In this section, we summarized the control programs that successfully used B. bassiana application as crop protection from 2009 to 2019.

\section{Against thrips in Thysanoptera}

The fungus $B$. bassiana strain RSB showed its effectiveness against western flower thrips, Frankliniella occidentalis (Thysanoptera: Thripidae) causing 69\%-96\% mortality at concentrations of $1 \times 10^{4}-1 \times 10^{7}$ conidia. $\mathrm{mL}^{-1}, 10$ days after inoculation of first instars. In laboratory and in greenhouse trials, RSB applied to broccoli foliage significantly reduced adult and larval populations (Gao et al. 2012). The second instar larvae and pupae of the thrips which had been attacked by predatory mites were markedly more susceptible to B. bassiana infection than non-attacked thrips (Wu et al. 2015). On cucumber grown in greenhouse, single application of either fungus B. bassiana or the predatory mite Neoseiulus barkeri significantly reduced both larval and adult $F$. occidentalis populations (Wu et al. 2016).

Wu et al. (2013) performed laboratory and greenhouse evaluation of a new entomopathogenic strain of B. bassiana for control of the onion thrips Thrips tabaci. Among 20 isolates of B. bassiana tested for their virulence against $T$. tabaci in laboratory bioassays, strain SZ-26 was found to be the most virulent, causing $83 \%-$ $100 \%$ mortality in adults at $1 \times 10^{7}$ conidia. $\mathrm{mL}^{-1}$ after its application for 4-7 days. The following greenhouse experiments revealed that the strain SZ-26 significantly reduced adult and larval numbers.

Furthermore, using sub-lethal doses of neem tree extract in combination with $B$. bassiana improved the effectiveness of the control strategy against $T$. tabaci (Thysanoptera: Thripidae) while reduced the amount of insecticide used (Al-mazra'awi et al. 2009).

\section{Against Coleoptera in palm tree and stored grains}

The entomopathogenic fungus $B$. bassiana was reported to be effective against the palm weevil Rhynchophorus ferrugineus (Oilv.) (Coleoptera: Curculionidae) when applied three methods (Injection of B. bassiana in naturally infested palm trees, periodical dusting application of fungal spores on palm trees, release of contaminated males of red palm weevil with fungal spores). Injection of naturally infested palm trees using B. bassiana reduced by up $90 \%$ of the weevil population (Sewify et al. 2009). In laboratory studies, Dembilio et al. (2010) showed that an indigenous strain CECT-20752 of $B$. bassiana obtained from a naturally infected $R$. ferrugineus pupa was able to infect eggs, larvae and adults of $R$. ferrugineus with median lethal concentration $\left(L C_{50}\right)$ ranging from $6.3 \times 10^{7}$ to $3.0 \times 10^{9}$ conidia. $\mathrm{mL}^{-1}$.

Efficacy of B. bassiana against Cosmopolites sordidus (Germar, 1824) (Coleoptera: Curculionidae) was observed when the beetles were immersed in a fungal suspension at a concentration of $1.12 \times 10^{9}$ conidia. $\mathrm{mL}^{-1}$ with $54 \%$ to $66 \%$ mortality for strains (IBCB 74, IBCB 87 and $I B C B$ 146), and the same as sporulation rate for the three strains (Almeida et al. 2009). Also, infection after B. bassiana application against Ips typographus (Coleoptera: Curculionidae) caused up to $92 \%$ mortality in the weevil (Mudrončeková et al. 2013).

The B. bassiana strain PPRI5339 [BroadBand, an emulsifiable spore concentrate (EC) formulation] and Metarhizium anisoplae have been suggested for management of Polyphylla fullo (L.) (Coleoptera: Scarabaeidae) (Erler and Ates 2015). Young larvae ( $1^{\text {st }}$ and $2^{\text {nd }}$ instars) were more susceptible to infection than the older ones ( $3^{\text {rd }}$ instar). The fungal formulation when applied caused up to $79.8 \%$ and $71.6 \%$ mortality in young and older larvae, respectively.

Essays in low-land farm using two flea beetle susceptible okra varieties (NH99/DA and LD88/1-8-5-2) with isolate of Botanigard 22WP-B. bassiana strain GHA mixed with water in a knapsack sprayer and applied to okra leaves from 2 weeks after planting plants at 3-57 g per1.5 L of water and repeated at weekly interval for 6 weeks revealed that entomopathogenic fungus, $B$. 
bassiana reduced the number of Podagrica spp. (Coleoptera: Chrysomelidae) in treated okra plants and enhanced yield (Kudemepo et al. 2018). Moreover, Kaiser et al. (2016) reported a synergistic interaction between $B$. bassiana spores and oil formulation to control the Pollen beetles Meligethes spp.

The endophytic colonization of radiata pine (Pinus radiate De Don) was found to be effective in controlling the bark beetle pest in forest trees plantation (Brownbridge et al. 2012). Likewise, B. bassiana was effective against Ips avulsus Eichhoff (Coleoptera: Scolytidae) by inducing approximately $84 \%$ adult mortality compared with untreated control ( $14 \%$ mortality) (Olatinwo et al. 2018).

The formulated product BbWeevil ${ }^{\mathrm{m}}$ made of $B$. bassiana conidia was found to efficiently control the storage grain beetles Oryzaephilus surinamensis, Sitophilus granarius, Tribolium castaneum (Khashaveh et al. 2011). Likewise this product was effective against adults of Callosobruchus maculatus (F.) and S. granarius (L.) on stored grains in darkness $(27 \pm 2)^{\circ} \mathrm{C}$ and $(65 \pm 5) \%$ relative humidity (RH) (Shams et al. 2011).

It has been proved that the lower dose of the B. bassiana product can be used in storage systems where the predator Teretrius nigrescens (Lewis) was already established to control the larger grain borer (LGB), Prostephanus truncatus (Horn), a cosmopolitan and major storage pest of maize causing up to $48 \%$ dry weight loss (Nboyine et al. 2015).

\section{Against crop pests in Diptera, Lepidoptera and Hemiptera}

B. bassiana proved its effectiveness against Thaumastocoris peregrinus Carpintero \& Dellapé (Hemiptera: Thaumastocoridae), one pest of Eucalyptus camaldulensis, under laboratory conditions with mortality rate ranging from 37 to $80.1 \%$ after 10 days of application (Lorencetti et al. 2018).

The fungi B. bassiana, Metarhizium anisopliae (Metsch) Sor. and M. flavoviride (Gams \& Rozsypal) applied at a concentration of $1 \times 10^{7}$ conidia. $\mathrm{mL}^{-1}$ against the citrus pests (Ceratitis rosa Karsch, C. capitata Wiedemann (Diptera: Tephritidae) and Thaumatotibia leucotreta Meyrick (Lepidoptera: Tortricidae)), had significantly reduced adult populations in both insect pests compared with their effect on pupae in laboratory conditions. The estimated $L C_{50}$ values of the three fungal species ranged from $6.8 \times 10^{5}$ to $2.1 \times 10^{6}$ conidia $\cdot \mathrm{mL}^{-1}$ (Goble et al. 2011).

Wang et al. (2016) screened different B. bassiana strains against Dendrolimus punctatus (Lepidoptera: Lasiocampinae) and found that strains B-2, B-14 and B19 were more virulent (lethal time $50\left(L T_{50}\right)$ of B-2, B14 and B-19 were 7.63, 7.62 and $7.88 \mathrm{~d}$, respectively, and their $\mathrm{LC}_{50}$ were $0.63 \times 10^{6}, 0.96 \times 10^{6}$ and $0.78 \times 10^{6}$ conidia. $\mathrm{mL}^{-1}$, respectively) on $D$. punctatus, suggesting their high potential in biological control. According to Vijayavani et al. (2009), dry conidia of two B. bassiana strains SBT\#11 and SBT\#16 affected chrysalids of Spodoptera litura (Fab.) (Lepidoptera: Noctuidae) under laboratory conditions. Both strains of $B$. bassiana were highly pathogenic causing $100 \%$ mortality in S. litura. Their effect was conidial concentration dependent. SBT\#11 was more virulent with a lethal time 50 (LT50) of 5.1 days in laboratory compared with SBT\#16 with a $L T_{50}$ of 6 days. Fungal sporulation was observed in $87 \%$ of insect cadavers in the treated group. Hasyim et al. (2017) found that $2 \mathrm{~g} \cdot \mathrm{L}^{-1}$ water concentration of the entomopathogen fungi of $B$. bassiana and Verticillium lecanii induced the annihilation in S. exigua larvae up to 90\%.

Pathogenicity of the entomopathogenic fungi $M$. anisopliae and B. bassiana on larvae Helicoverpa armigera (Hübner) (Lepidoptera: Noctuidea) has been assessed by Douro Kpindou et al. (2012a, b) who observed that the isolate (Bb11, known as Bba5653) of B. bassiana was more efficient compared with Metarhizium (Met 31). These entomopathogenic fungi may be promising biological control agents against the cotton bollworm $H$. armigera. Likewise, Toffa-Mehinto et al. (2014) showed that B. bassiana isolate Bb115 (mortality rates ranged from $(65.8 \pm 3.5) \%$ (fifth instar) to $(79.0 \pm 3.0) \%$ (first instar), respectively) was a promising biological control agent against the legume pod borer Maruca vitrata (Lepidoptera: Crambidae).

Moreover, Karthikeyan and Selvanarayanan (2011) studied in vitro bioefficacy of B. bassiana (Bals.) Vuill against selected insect pests of cotton $H$. armigera, $S$. litura, Earias vittella Fabricius. Among the three concentrations, $0.25 \%$ recorded the highest mortality of $H$. armigera (86.67\%), S. litura (86.67\%) and E. vittella (73.33\%), respectively. When different concentrations of $B$. bassiana after $2^{\text {nd }}$ spray against diamondback month (Plutella xylostella Linn.) on cabbage (Brassica oleracea var. capitata) were tested in field and green house experiments, Kamal et al. (2018) reported that applying $2.4 \times 10^{8}$ conidia $\cdot \mathrm{mL}^{-1}$ recorded the highest reduction (72.64\%) of larval population and the most effective treatment with the highest cost-benefit ratio $(1: 6.04)$ as compared with other B. bassiana concentrations.

Likewise, Xu et al. (2011) used 7 strains of B. bassiana (D1worm-5, D1 worm-9, L2 worm-8, L1-1-1, D6 worm2, D10 worm-2, S9 worm-X-1) high virulent against the white worms of Ostrinia furnacalis Guenée (Lepidoptera: Crambidae) in China. The muscardine (sporulated dead worm) lethal rate has been $93 \%-100 \%$ at $1.06 \times 10^{10} \mathrm{~mL}^{-1}$ spores density.

Jaber and Ownley (2018) have reported that entomopathogenic fungi, often solely considered as insect 
pathogens, play additional roles in nature, including endophytism, plant disease antagonism, plant growth promotion, and rhizosphere colonization. The fungus $B$. bassiana is a fungal entomopathogen that can colonize plants endophytically and plays a role in protecting plants from herbivory attack and disease. A concentration of $10^{8}$ conidia.mL $\mathrm{m}^{-1}$ (in water) of $B$. bassiana applied either as a foliar spray or a soil drench reduced pests and disease attack in a common bean (Phaseolus vulgaris) (Parsa et al. 2013). Wraight et al. (2010) reported a high susceptibility of the second-instar larvae of several Lepidopteran pests including: diamondback moth (P. xylostella L. (DBM), European corn borer (ECB) (O. nubilalis), corn earworm (CEW) (H. zea), and fall armyworm (FAW) (S. frugiperda); beet armyworm (BAW) (S. exigua), black cutworm (BCW) (Agrotis ipsilon), cabbage worm (ICW) (Pieris rapae) and cabbage looper (CL) (Trichoplusia ni). Indeed, B. bassiana isolate 1200 exhibited higher virulence against all these pest species compared with the commercial B. bassiana strain GHA currently registered in the USA as BotaniGard. On the other hand, the isolate Bba5653 was found to cause 94\% mortality of DBM (P. xylostella) larvae with a cabbage yield of $44.1 \mathrm{t} \cdot \mathrm{hm}^{-2}$ in plots treated with water formulation at $1 \mathrm{~kg}$ conidia powder $(\mathrm{CP})$ per hectare (Vodouhe et al. 2009). Likewise, colonization of cotton plants by the endophytes $B$. bassiana or Lecanicillium lecanii slowed down the reproduction and feeding in Aphis gossypii Glover (Hemiptera: Aphididae). Moreover, the consumption of wheat leaves colonized by either $B$. bassiana or Aspergillus parasiticus slowed down the growth of Chortoicetes terminifera (Walker, 1870) nymphs suggesting a possible role for endophytic entomopathogens in the regulation of insect populations (Gurulingappa et al. 2010). Also, neem oil formulation (Neemseto ) at a concentration less than $0.25 \%$, in combination with $B$. bassiana CG001 isolate could be applied to control the aphid Lipaphis erysimi (Kalt.) (Hemiptera: Aphididae) in kale (Brassica oleracea var. acephala) (Araujo et al. 2009).

In greenhouse and field experiments, commercialized B. bassiana strains ATCC74040 and GHA were applied on grapevine (Vitis vinifera (L.)) leaves either as conidial suspensions or as a formulated product (Naturalis, strain ATCC74040) to control piercing-sucking insects (Rondot and Reineke 2018). Endophytic survival of $B$. bassiana inside leaf tissues of seven-week-old potted plants was evident for at least 21 days after inoculation, irrespective of the inoculum used. The endophytic colonization of grapewine plants by $B$. bassiana reduced infestation rate and growth of vine mealybug Planococcus ficus (Signoret, 1875) (Hemiptera: Pseudococcidae). In the vineyard $B$. bassiana has been detected as an endophyte in mature grapevine plants, 5 weeks after last application with significant reduction in grape leafhopper, Empoasca vitis (Gothe, 1875) (Hemiptera: Cicadellidae) infestation.

\section{Against Acarians}

The application of $\mathrm{B}$. bassiana isolates $444 \mathrm{Bb}$ and $445 \mathrm{Bb}$ with conidial suspensions at a concentration of $10^{6}$ conidia. $\mathrm{mL}^{-1}$ against Tetranychus urticae Koch. (Acari: Tetranychidae) induced drastic reduction in mycosis caused by this acarina (Draganova and Simova 2010). The mean mortality values of host individuals were $(83.78 \pm 3.62) \%$ and $(68.49 \pm 4.28) \%$ respectively on the first day for isolates $444 \mathrm{Bb}$ and $445 \mathrm{Bb}$, but up to $100 \%$ for both isolates on the fourth day.

A single application of $B$. bassiana $\left(1 \times 10^{8}\right.$ spores $\cdot \mathrm{mL}^{-1}$ ) suspensiom after the release at low rate of the phytoseiid predatory mite, Phytoseiulus persimilis Athias-Henriot (10 prey:1 predator) successfully controlled T. urticae Koch population $(P<0.001)$, with the lowest corrected leaf damage (1.5\%) on bean plants (Ullah and Lim 2017). The effectiveness of $B$. bassiana combined with Purpureocillium lilacinum Thom (1910) (Hypocreales, Ophiocordycipitaceae) TR1 was reported on $T$. urticae by Yeșlayer (2018) who recorded a mortality rate of $66.6 \%$ at the highest doses $\left(10^{8}\right.$ conidia. $\left.\mathrm{mL}^{-1}\right)$. In the Table 1, more information is depicted about the control programs that successfully used B. bassiana for crop protection from 2009 to 2019.

\section{Benefits of using B. bassiana}

The entomopathogenic fungus $B$. bassiana is one of the most effective agents in biological control widely described in the literature. It's found in all soil types (Jamal 2008; Lambert 2010). Different isolates were identified to attack a wide range of insects (707 species belong to 15 orders) and mites (13 species) (Lambert 2010; Zimmermann 2007). The use of B. bassiana is an environmentally friendly control mean compared to chemical pesticides. In addition to being more environmentally sound control method, B. bassiana is harmless to human health (Althouse et al. 1997; Faria and Wraight 2001). For some authors, the consumption of B. bassiana extracts would have positive effects on the immune system (Id. 2007 cited by Lambert 2010). Allergic reactions in people manipulating the fungus were scarcely reported (Lambert 2010). Furthermore, it is easy and relatively cheap to culture and maintain several B. bassiana strains in laboratory conditions compared with the production costs of chemical pesticides. In addition, solutions containing $B$. bassiana conidia can easily be applied in field using equipment and application method like those of synthetic insecticides (Fréchette et al. 2009). 
Compared with other biocontrol agents acting by ingestion, a simple contact of $B$. bassiana with the insect is sufficient to trigger infection of susceptible host in suitable environmental conditions and insect physiology. Thus, this entomopathogenic fungus kills both adult and immature stages (eggs, larvae) causing the so-called "white muscardine" disease (Barron 2001, Groden 1999). The spores' lifespan, once in the field was found to vary greatly according to the environment conditions, between $24 \mathrm{~h}$ to 26 days (Jamal 2008). However, some forms of resistance can survive longer, to ensure a longterm control (Lambert 2010).

According to Sabbahi (2008), the insecticidal activity of $B$. bassiana is faster than other entomopathogenic agents with a longer lifespan; conidia can persist in the environment through the spread of enzootic or epizootic diseases. Moreover, its effect on beneficial insects and other non-target organisms was limited. Finally, it is not theoretically possible for insects to develop resistance to $B$. bassiana because the fungus simultaneously uses several modes of action and as a living organism, it can adapt to various host changes.

For all these reasons, the use of B. bassiana as a biological insecticide is seen as a potential alternative to chemical insecticides.

\section{Constraints related to the use of B. bassiana}

\section{Environmental constraints}

The use of entomopathogenic fungi such as B. bassiana in pest control is not without constraints. In laboratory conditions, the fungus can kill insects 3 to 6 days after infection (Inglis et al. 2001). Field conditions may be suboptimal, leading to prolonged disease initiation and progression in the host; the expected lethal effect may take longer (Sabbahi 2008).

The efficacy of $B$. bassiana depends mainly on environmental abiotic factors, including moisture, temperature, precipitation, and ultraviolet (UV) radiation (Jaronski 2010; Fernandes et al. 2015; McCoy et al. 2002) for inoculum buildup and storage. Thus, according to the results from the studies carried out by Teng (1962) on the biology of $B$. bassiana, the favourable temperature for mycelial growth ranged between $13{ }^{\circ} \mathrm{C}$ and $36^{\circ} \mathrm{C}$. Mycelium development ceased at $8{ }^{\circ} \mathrm{C}$ and $40^{\circ} \mathrm{C}$. The optimal temperature for spore germination and mycelial growth was $24^{\circ} \mathrm{C}$, which, according to laboratory tests with Dendrolimus punctatus Walker (1855), was also favourable to infection. The upper general temperature limit for growth was $34^{\circ} \mathrm{C}$ to $36^{\circ} \mathrm{C}$. Higher temperatures can significantly reduce the fungal production efficiency (Noma and Strickler 1999; Ugine 2011). Similarly, the optimal temperature $\left(30^{\circ} \mathrm{C}\right)$ for spore production was reported by $30^{\circ} \mathrm{C}$ according to Teng (1962). Although the relative humidity most suitable for mycelial growth and spore germination is $100 \%$, spores of some strains of $B$. bassiana can germinate at a low relative humidity (56.8\%). On the other hand, lower percentages of relative humidity $(25 \%-50 \%)$ favored sporulation. However, $B$. bassiana can tolerate a relatively low humidity according to other authors. Fargues et al. (1997), showed that B. bassiana requires for its development the existing moisture in host micro-habitat or in the microenvironment of the host body surfaces (Faria and Wraight 2001), which would allow it to evolve in more severe environemtal conditions. Conidia of hyphomycetes (including formerly B. bassiana) fungi strongly adhere to insect cuticle (Boucias et al. 1991), so that precipitation does not induce higher conidia loss (Burges 1998). However, other studies showed that precipitation was responsible for significant loss of $B$. bassiana conidia adhered to the leaves of some monocotyledonous and dicotyledonous plants (Inglis et al. 2000; Inyang et al. 2000). Solar radiation (ultraviolet type A and B) (Fernandes et al. 2015; Jaronski 2010; Inglis et al. 1993) can rapidly inactivate $B$. bassiana conidia. This phenomenon reduces the effectiveness and persistence of $B$. bassiana on treated leaves. Cagán and Švercel (2001) observed that an increased UV radiation induced a decline in the efficacy of B.bassiana against Ostrinia nubilalis Hübner (Lepidoptera: Crambidae). Thus, climatic conditions could influence the physiology of the fungus, its ability to infect the host, the infection progression within the living or dead host, cadaver sporulation, the dissemination ability and survival of infectious conidia, also the host's susceptibility or resistance to infection (Sabbahi 2008).

\section{Compatibility of $B$. bassiana with chemical pesticides}

The effectiveness of a microbial control agent could be improved by combining it with low rates of pesticides (Islam and Omar 2012). When the interaction becomes synergistic, the combination would improve the effectiveness of the biological control agent while reducing the side effects of pesticides. However, achieving the synergistic interaction is not always easy so that in the case of $B$. bassiana, it is possible to get an antagonistic effect. And several pesticides can affect survival of $B$. bassiana depending on the strains. For instance, lufenuron even at low doses was found to be incompatible with B. bassiana (strain MTCC-984) (Purwar and Sachan 2005). Some chemical pesticides namely imidacloprid, flufenoxuron, teflubenzuron + phuzalon, endosulfan and amitraz have been used to assess their effect on conidial germination, vegetative growth and sporulation. Of all these chemical pesticides, only Imidacloprid was compatible with $B$. bassiana isolate DEBI008. On the other hand, flufenoxuron was incompatible with $B$. bassiana due to complete inhibition of its development (Alizadeh et al. 2007). In other studies, Amutha et al. (2010) investigated the compatibility of $B$. bassiana with twelve (12) insecticides for control of cotton pests by the 
technique of poisoned feeds and found only chlorpyriphos $20 \%$ (mass fraction, the same as below) emulsifiable concentrate (EC) as less toxic to B. bassiana, while spinosad (45\% suspension concentrate (SC)), econeem (1\%), quinalphos (25\% EC), acetampride (20\%), endosulfan (35\% EC) and thiodicarb (75 wettable powder (WP)) were slightly toxic. Imidacloprid $(17.80 \%$ solution for seed treatment (LS)) and triazophos (40\% EC) were moderately toxic and profenofos (50\% EC), indoxacarb $(14.5 \%$ EC) and methyldemeton were highly toxic. Furthermore after assessing the compatibility of five pesticides (phoxim, thiamethoxam, clothianidin, $\lambda$ cyhalothrin and $\beta$-cypermethrin) commonly used against Bradysia odoriphaga (Diptera: Sciaridae) with a high virulence strain of $B$. bassiana YB8, Fan et al. (2017) recommended the application of thiamethoxam and clothianidin in combination with $B$. bassiana for control of $B$. odoriphaga, while phoxim, $\lambda$-cyhalothrin and $\beta$ cypermethrin could be used only at low concentration. In addition, some acaricides belonging to the organophosphorus and organostanic chemical groups were reported to significantly affect conidia germination and the vegetative growth and sporulation of $B$. bassiana (de Oliveira and Neves 2004).

Another constraint is related to the timing and synchronization of $B$. bassiana applications with some chemical pesticides. For example, the efficacy of $B$. bassiana against adults of Lygus lineolaris Palisot de Beauvois (1818) (Heteroptera: Miridae) was not altered within four days delay before the application of fungicides. But when fungicides were applied before the use of $B$. bassi$a n a$, this resulted in an antagonistic effect with lower mortality of L. lineolaris adult population (Kouassi et al. 2003c reported by Sabbahi 2008). Herbicides and plant growth regulators have been extensively used in most agrosystems, and their compatibility with entomopathogenic fungi was not often established (Sabbahi 2008). But, glufosinate ammonium was not compatible with $B$. bassiana applied to control the potato beetle (Todorova et al. 1998). Indeed, this herbicide had an inhibitory effect on mycelial growth and sporulation of B. bassiana. However, diquat had a stimulating effect on the insecticidal activity of B. bassiana causing $50 \%-76.6 \%$ mortality of adult Colorado potato beetle Leptinotarsa decemlineata (Say).

\section{Constraints related to the compatibility of $B$. bassiana with biological control agents}

Few studies have focused on the possibility of combining an entomopathogen such as viruses, protozoa and bacteria with $B$. bassiana in order to increase control efficiency. In addition, the antagonism phenomenon between microorganisms constitutes a major limit to the combination of biological control agents. A biopesticide used to control a pest may become ineffective in the presence of an antagonist agent in the field. For instance, $B$. bassiana is susceptible to some pathogenic fungi including Penicillium urticae which inhibits conidial germination and mycelial growth through a metabolite, patulin (Shields et al. 1981). The application method can affect the interactions between $B$. bassiana and other biocontrol agents. Al-mazra'awi et al. (2009) showed that, in the mixture application, onion thrips adults treated with $B$. bassiana and sub-lethal doses of neem tree extracts exhibited higher mortalities than insects treated with the fungus alone but without synergistic interactions. However, the two control agents interacted antagonistically when neem tree extract was used at full field application rate. But, in the topical application of B. bassi$a n a$ and neem tree extract drenching, the treated insects exhibited mortalities higher than when each control agent was used alone and the two control agents interacted synergistically at sub-lethal doses of the neem tree extract. Togbé et al. (2014) evaluated the synergistic effects of $B$. bassiana (Bals.-Criv. Vuill.) (isolate Bb11) and Bacillus thuringiensis var. kurstaki (Berliner) (Bt) with neem oil in three agroecological zones in Benin and reported an absence of synergy between neem oil and B. bassiana, neem oil and $B t$ against cotton pests.

Nevertheless, Lewis et al. (1996) have shown that the combination of $B t$ and B. bassiana in maize field increased mortality of corn borer larvae, Ostrinia nubilalis (Hübner). Also, B. bassiana offers a way forward for the biological control of greenhouse crops. According to Jacobson et al. (2010), B. bassiana-based mycopesticide could be used as a second line of defense to support the preventive control of Amblyseius cucumeris (Acarina: Phytoseiidae) against berry thrips populations, Frankliniella occidentalis Pergande (Thysanoptera: Thripidae) feeding on cucumbers in a greenhouse. Combined application of B. bassiana (Balsamo) Vuillemin and predatory mite Neoseiulus barkeri Hughes were effective against Frankliniella occidentalis Pergande (Thysanoptera: Thripidae) (Wu et al. 2015).

Barbercheck and Kaya (1991) reported that coinfections by nematodes (Steinernema carpocapsae (Weiser) or Heterorhabditis bacteriophora Poinar and $B$. bassiana (Bals.) Vuill could speed the rate of lethal infection with high mortality in treated $S$. exigua (Hübner) populations.

Regarding the registration of a microbiological control agent, it's necessary to ensure the safety for non-target organisms, especially predatory insects and parasitoids (Inglis et al. 2001). The entomopathogen B. bassiana has a large spectrum of host insect, and its pathogenicity and virulence vary with isolates and host insects (Goettel et al. 1990). It should be important that new research activities focus on parasitoids, generalist predators, 
Table 1 Summary of the control programs that successfully used Beauveria bassiana for crop protection from 2009 to 2019

\begin{tabular}{|c|c|c|c|c|c|c|}
\hline Continent & Country or region & $\begin{array}{l}\text { Application } \\
\text { strategy (alone } \\
\text { or combined } \\
\text { with other } \\
\text { biocontrol } \\
\text { agents) }\end{array}$ & Target pest & $\begin{array}{l}\text { Crops / bio- } \\
\text { assay condition }\end{array}$ & Inoculation Method & Authors \\
\hline Africa & Benin & Alone & $\begin{array}{l}\text { Diamondback } \\
\text { moth ( } \\
\text { Plutella xylostella } \\
\text { L.) (Lepidoptera: } \\
\text { Plutellidae) }\end{array}$ & Cabbage leaves & $\begin{array}{l}\text { Each disinfected leaf } \\
\text { was dipped individually } \\
\text { into } 10^{8} \mathrm{~mL}^{-1} \text { conidia } \\
\text { suspension (inoculum) } \\
\text { of tested fungal specie } \\
\text { for } 1 \mathrm{~min} \text { and introduced } \\
\text { into a } 2.5 \mathrm{~cm} \times 7 \mathrm{~cm} \\
\text { plastic tube }\end{array}$ & $\begin{array}{l}\text { Vodouhe et al. } \\
\text { (2009) }\end{array}$ \\
\hline Africa & Benin & Alone & $\begin{array}{l}\text { Cotton bollworm } \\
\text { H. armigera. (Hübner) } \\
\text { (Lepidoptera: Noctuidae) }\end{array}$ & $\begin{array}{l}\text { Laboratory } \\
\text { experimentation }\end{array}$ & $\begin{array}{l}\text { Applying topically to } \\
\text { inoculate larvae by two } \\
\text { B. bassiana isolates } \\
\text { (Bb11 and Bb12) at } 10^{8} \\
\text { conidia.mL } \mathrm{L}^{-1} \text { on the third, } \\
\text { fourth, fifth and the sixth } \\
\text { instars of } H \text {. armigera }\end{array}$ & $\begin{array}{l}\text { Douro } \\
\text { et al. (2012b) }\end{array}$ \\
\hline Africa & Benin & Alone & $\begin{array}{l}\text { Cotton bollworm } \\
\text { H. armigera. (Hübner) } \\
\text { (Lepidoptera: Noctuidae) }\end{array}$ & $\begin{array}{l}\text { Laboratory } \\
\text { experimentation }\end{array}$ & $\begin{array}{l}\text { Applying topically to } \\
\text { inoculate larvae by } \\
\text { B.bassiana (isolate } \mathrm{Bb} 11 \text { ) } \\
\text { at } 0,10^{4}, 10^{5}, 10^{6}, 10^{7} \\
\text { conidia. } \mathrm{mL}^{-1} \text { on fourth } \\
\text { instars of } \mathrm{H} \text {. armigera }\end{array}$ & $\begin{array}{l}\text { Douro } \\
\text { et al. (2012a) }\end{array}$ \\
\hline Africa & Benin & $\begin{array}{l}\text { Combined } \\
\text { with Neem } \\
\text { (Azadirachta } \\
\text { indica) oil }\end{array}$ & $\begin{array}{l}\text { Earias spp., Diparopsis } \\
\text { watersi Rothschild } \\
\text { (Lepidoptera: Noctuidae), } \\
\text { H. armigera, P. gossypiella, } \\
\text { C. leucotreta and } \\
\text { Dysdercus voelkeri } \\
\text { Schmidt (Hemiptera: } \\
\text { Pyrrhocoridae) }\end{array}$ & $\begin{array}{l}\text { Cotton (Field } \\
\text { evaluation) }\end{array}$ & Foliar sprays & $\begin{array}{l}\text { Togbé } \\
\text { et al. (2014) }\end{array}$ \\
\hline Africa & Benin & Alone & $\begin{array}{l}\text { Maruca vitrata } \\
\text { (Lepidoptera: } \\
\text { Crambidae) }\end{array}$ & $\begin{array}{l}\text { Experiments under } \\
\text { laboratory conditions }\end{array}$ & $\begin{array}{l}\text { Applying } 2 \mu \mathrm{L} \text { of } \\
\text { conidia suspension } \\
\left(10^{7}, 10^{8}, 10^{9} \text { and } 10^{10}\right. \\
\left.\text { conidia. } \mathrm{mL}^{-1}\right) \text { formulated } \\
\text { in peanut oil on different } \\
\text { larval stages (first, second, } \\
\text { third, fourth and the } \\
\text { fifth instars) }\end{array}$ & $\begin{array}{l}\text { Toffa-Mehinto et al. } \\
\text { (2014) }\end{array}$ \\
\hline \multirow[t]{3}{*}{ Africa } & Egypt & Alone & $\begin{array}{l}\text { Red Palm weevil ( } R \text {. } \\
\text { ferrugineus (Oliv.)) } \\
\text { (Coleoptera: Curculionidae) }\end{array}$ & Red Palm trees & $\begin{array}{l}\text { 1-injection of } B \text {. bassiana } \\
\text { in naturally infested palm } \\
\text { trees }\end{array}$ & Sewify et al. (2009) \\
\hline & & & & & $\begin{array}{l}\text { 2-periodical dusting } \\
\text { application of fungal } \\
\text { spores on palm trees }\end{array}$ & \\
\hline & & & & & $\begin{array}{l}\text { 3- release of contaminated } \\
\text { males of red palm weevil } \\
\text { with fungal spores }\end{array}$ & \\
\hline Africa & Egypt & Alone & $\begin{array}{l}\text { Red Palm weevil ( } R . \\
\text { ferrugineus (Oliv.)) } \\
\text { (Coleoptera: Curculionidae) }\end{array}$ & $\begin{array}{l}\text { Red Palm trees under } \\
\text { Laboratory and Field } \\
\text { Conditions. }\end{array}$ & - & $\begin{array}{l}\text { El-Sufty et al. } \\
\text { (2009) }\end{array}$ \\
\hline Africa & Kenya & $\begin{array}{l}\text { Alone or } \\
\text { Combined } \\
\text { with The } \\
\text { predator } \\
\text { Teretrius } \\
\text { nigrescens } \\
\text { Lewis (Col.: } \\
\text { Histeridae) }\end{array}$ & $\begin{array}{l}\text { Larger grain borer ( } \\
\text { Prostephanus } \\
\text { truncatus (Horn)) }\end{array}$ & stored maize & $\begin{array}{l}\text { Two doses }\left(1 \times 10^{9}\right. \\
\text { CFU. } \mathrm{kg}^{-1} \text { maize and } \\
\left.1 \times 10^{10} \mathrm{CFU} \cdot \mathrm{kg}^{-1} \text { maize }\right) \\
\text { of } B \text {. bassiana, with and } \\
\text { without the predator, } T \text {. } \\
\text { nigrescens, were applied } \\
\text { to maize infested with } \\
\text { P. truncatus }\end{array}$ & $\begin{array}{l}\text { Nboyine et al. } \\
\text { (2015) }\end{array}$ \\
\hline
\end{tabular}

Red Palm, bioassay in - immersion of eggs,

Dembilio et al. 
Table 1 Summary of the control programs that successfully used Beauveria bassiana for crop protection from 2009 to 2019 (Continued)

\begin{tabular}{|c|c|c|c|c|c|c|}
\hline Continent & Country or region & $\begin{array}{l}\text { Application } \\
\text { strategy (alone } \\
\text { or combined } \\
\text { with other } \\
\text { biocontrol } \\
\text { agents) }\end{array}$ & Target pest & $\begin{array}{l}\text { Crops / bio- } \\
\text { assay condition }\end{array}$ & Inoculation Method & Authors \\
\hline & Basin & & $\begin{array}{l}\text { Rhynchophorus } \\
\text { ferrugineus (Olivier 1790)) } \\
\text { (Coleoptera: Curculionidae) }\end{array}$ & laboratory conditions & $\begin{array}{l}\text { larvae and adults in } \\
\text { conidial aqueous } \\
\text { suspension at } \\
\text { different concentrations }\end{array}$ & (2010) \\
\hline Africa & Nigeria & Alone & $\begin{array}{l}\text { Flea beetle Podagrica } \\
\text { spp. (Coleoptera: } \\
\text { Chrysomelidae) }\end{array}$ & $\begin{array}{l}\text { Okra (Abelmoschus } \\
\text { esculentus) (L.) } \\
\text { Moench }\end{array}$ & $\begin{array}{l}\text { Botanigard 22WP } \\
\text { (Beauveria bassiana } \\
\text { strain GHA) was mixed } \\
\text { with water in a knapsack } \\
\text { sprayer and applied toon } \\
\text { okra leaves from } 2 \text { weeks } \\
\text { after planting plants } \\
\text { at } 3-57 \mathrm{~g} \text { per } 1.5 \mathrm{~L} \text { of water } \\
\text { and repeated at weekly } \\
\text { interval for } 6 \text { weeks. }\end{array}$ & $\begin{array}{l}\text { Kudemepo } \\
\text { et al. (2018) }\end{array}$ \\
\hline America & Brazil & $\begin{array}{l}\text { Alone and } \\
\text { Combined } \\
\text { with neem oil } \\
\text { formulation } \\
\text { (Neemseto }^{\oplus} \text {. }\end{array}$ & $\begin{array}{l}\text { The aphid Lipaphis } \\
\text { erysimi (Kalt.) } \\
\text { (Hemiptera: Aphididae) }\end{array}$ & $\begin{array}{l}\text { Kale, Brassica oleracea } \\
\text { var. acephala D.C }\end{array}$ & $\begin{array}{l}\text { Leaf discs dipping or } \\
\text { spraying the aphids }\end{array}$ & $\begin{array}{l}\text { Araujo et al. } \\
(2009)\end{array}$ \\
\hline America & Brazil & Alone & $\begin{array}{l}\text { Cosmopolites sordidus } \\
\text { adults (Germar, 1824) } \\
\text { (Coleoptera: } \\
\text { Curculionidae). }\end{array}$ & $\begin{array}{l}\text { Bioassay in } \\
\text { Laboratory }\end{array}$ & $\begin{array}{l}\text { The beetles were } \\
\text { immersed in a fungal } \\
\text { suspension in } \\
\text { the concentration of } \\
1.12 \times 10^{9} \text { conidia. } \mathrm{mL}^{-1}\end{array}$ & $\begin{array}{l}\text { Almeida } \\
\text { et al. (2009) }\end{array}$ \\
\hline America & Brazil & Alone & $\begin{array}{l}\text { Thaumastocoris } \\
\text { peregrinus (Hemiptera: } \\
\text { Thaumastocoridae) }\end{array}$ & $\begin{array}{l}\text { Eucalyptus } \\
\text { camaldulensis, }\end{array}$ & $\begin{array}{l}\text { At } 1.0 \times 10^{8} \text { conidia. } \\
\mathrm{mL}^{-1} \text {, solution was } \\
\text { applied on leaves of } \\
\text { Eucalyptus camaldulensis, } \\
\text { provided as food for the } \\
\text { insect substrates }\end{array}$ & $\begin{array}{l}\text { Lorencetti } \\
\text { et al. (2018) }\end{array}$ \\
\hline America & Colombia & Alone & $\begin{array}{l}\text { Various pests species } \\
\text { and diseases }\end{array}$ & Phaseolus vulgaris & $\begin{array}{l}10^{8} \text { conidiamL }^{-1} \text { (or water) } \\
\text { applied either as a foliar } \\
\text { spray or a soil drench }\end{array}$ & $\begin{array}{l}\text { Parsa et al. } \\
(2013)\end{array}$ \\
\hline America & USA & Alone & $\begin{array}{l}\text { The diamondback } \\
\text { moth (Plutella xylostella) } \\
\text {, European corn } \\
\text { borer (Ostrinia nubilalis), } \\
\text { corn earworm } \\
\text { (Helicoverpa zea), } \\
\text { and fall armyworm } \\
\text { (Spodoptera frugiperda); } \\
\text { beet armyworm } \\
\text { (Spodoptera exigua), black } \\
\text { cutworm (Agrotis ipsilon), } \\
\text { cabbage worm } \\
\text { (Pieris rapae) and } \\
\text { cabbage looper } \\
\text { (Trichoplusia ni). }\end{array}$ & $\begin{array}{l}\text { Bio-assay in } \\
\text { Laboratory }\end{array}$ & $\begin{array}{l}\text { Larvae were topically } \\
\text { sprayed and maintained } \\
\text { on the treated substrate } \\
\text { for } 24 \mathrm{~h} \text { at } 100 \% \text { relative } \\
\text { humidity }\end{array}$ & $\begin{array}{l}\text { Wraight et al. } \\
\text { (2010) }\end{array}$ \\
\hline America & USA & Alone & $\begin{array}{l}\text { The small southern } \\
\text { pine engraver, Ips } \\
\text { avulsus Eichhoff } \\
\text { (Coleoptera: Scolytidae) }\end{array}$ & Pine bolt & $\begin{array}{l}\text { Field treatment by a } \\
\text { commercial preparation } \\
\text { of } B \text {. bassiana in } \\
\text { protecting pine host plant } \\
\text { tissue from colonization }\end{array}$ & $\begin{array}{l}\text { Olatinwo } \\
\text { et al. (2018) }\end{array}$ \\
\hline - & - & Alone & $\begin{array}{l}\text { Citrus insect pests, } \\
\text { Ceratitis rosa Karsch, } \\
\text { C. capitata Wiedemann } \\
\text { (Diptera: Tephritidae) } \\
\text { and Thaumatotibia }\end{array}$ & $\begin{array}{l}\text { In laboratory } \\
\text { conditions }\end{array}$ & - & $\begin{array}{l}\text { Goble et al. } \\
\text { (2011) }\end{array}$ \\
\hline
\end{tabular}


Table 1 Summary of the control programs that successfully used Beauveria bassiana for crop protection from 2009 to 2019 (Continued)

\begin{tabular}{|c|c|c|c|c|c|c|}
\hline Continent & Country or region & $\begin{array}{l}\text { Application } \\
\text { strategy (alone } \\
\text { or combined } \\
\text { with other } \\
\text { biocontrol } \\
\text { agents) }\end{array}$ & Target pest & $\begin{array}{l}\text { Crops / bio- } \\
\text { assay condition }\end{array}$ & Inoculation Method & Authors \\
\hline & & & $\begin{array}{l}\text { leucotreta Meyrick } \\
\text { (Lepidoptera: Tortricidae) }\end{array}$ & & & \\
\hline Asia & China & Alone & $\begin{array}{l}\text { The white worms of } \\
\text { Ostrinia furnacalis } \\
\text { Guenée (Lepidoptera: } \\
\text { Crambidae) in China }\end{array}$ & $\begin{array}{l}\text { In laboratory } \\
\text { conditions }\end{array}$ & - & Xu et al. (2011) \\
\hline Asia & China & Alone & $\begin{array}{l}\text { The onion thrips Thrips } \\
\text { tabaci 'adult and larval } \\
\text { stages' }\end{array}$ & $\begin{array}{l}\text { Broccoli, onion: in } \\
\text { laboratory and } \\
\text { greenhouse } \\
\text { evaluation }\end{array}$ & $\begin{array}{l}\text { Apply at } \\
1 \times 10^{7} \mathrm{~mL}^{-1} \text { conidia }\end{array}$ & Wu et al. (2013) \\
\hline Asia & China & $\begin{array}{l}\text { Alone and } \\
\text { Combined } \\
\text { with } \\
\text { predatory } \\
\text { mite } \\
\text { Neoseiulus } \\
\text { barkeri } \\
\text { Hughes } \\
\text { (Acarina: } \\
\text { Phytoseiidae) }\end{array}$ & $\begin{array}{l}\text { The western flower thrips } \\
\text { (Frankliniella occidentalis) }\end{array}$ & $\begin{array}{l}\text { Greenhouse } \\
\text { cucumber }\end{array}$ & - & Wu et al. (2016) \\
\hline Asia & China & Alone & Dendrolimus punctatus & $\begin{array}{l}\text { Bioassay in laboratory } \\
\text { conditions }\end{array}$ & $\begin{array}{l}\text { By dipping larvae } \\
\text { with spore suspensions }\end{array}$ & $\begin{array}{l}\text { Wang et al. } \\
\text { (2016) }\end{array}$ \\
\hline Asia & India & Alone & $\begin{array}{l}\text { The diamondback Moth, } \\
\text { Plutella xylostella Linn.) }\end{array}$ & $\begin{array}{l}\text { Cabbage Brassica } \\
\text { oleracea var. capitata }\end{array}$ & $\begin{array}{l}\text { Spraying of different } \\
\text { concentrations of } \\
\text { B. bassiana }\end{array}$ & $\begin{array}{l}\text { Kamal et al. } \\
\text { (2018). }\end{array}$ \\
\hline Asia & India & Alone & $\begin{array}{l}\text { H. armigera, Spodoptera } \\
\text { litura Fabricius, } \\
\text { Earias vittella Fabricius, } \\
\text { Aphis gossypii Glover, } \\
\text { Bemisia tabaci Gennadius } \\
\text { and Amrasca devastans } \\
\text { Distant }\end{array}$ & $\begin{array}{l}\text { Bioassay in laboratory } \\
\text { conditions }\end{array}$ & $\begin{array}{l}\text { The liquid formulations } \\
\text { tested were Beevicide } \\
\text { and sprayed }\end{array}$ & $\begin{array}{l}\text { Karthikeyan and } \\
\text { Selvanarayanan } \\
\text { (2011) }\end{array}$ \\
\hline Asia & $\begin{array}{l}\text { Indian } \\
\text { subcontinent }\end{array}$ & Alone & $\begin{array}{l}\text { Spodoptera litura (Fab.), } \\
\text { (Lepidoptera: Noctuidae) }\end{array}$ & $\begin{array}{l}\text { Bio-assay in } \\
\text { laboratory using fresh } \\
\text { cotton leaves }\end{array}$ & $\begin{array}{l}\text { The fungal inoculum } \\
(10 \mathrm{~mL} \text { per insect individual } \\
\text { of aqueous suspension } \\
\text { of } 10^{8} \text { conidia. } \mathrm{mL}^{-1} \text { with } \\
0.02 \% \text { Tween } 80 \text { ) was } \\
\text { sprayed on the larvae }\end{array}$ & $\begin{array}{l}\text { Vijayavani } \\
\text { et al. (2009). }\end{array}$ \\
\hline - & - & $\begin{array}{l}\text { Combined } \\
\text { with the } \\
\text { predactor } \\
\text { Neoseiulus } \\
\text { barkeri (Acari: } \\
\text { Phytoseidae) }\end{array}$ & $\begin{array}{l}\text { Frankliniella occidentalis } \\
\text { Pergande (Thysanoptera: } \\
\text { Thripidae) }\end{array}$ & $\begin{array}{l}\text { Bioassay in laboratory } \\
\text { conditions }\end{array}$ & $1.9 \times 10^{3} \mathrm{CFU}$ per insect & Wu et al. (2015) \\
\hline Asia & Iran & Alone & $\begin{array}{l}\text { Oryzaephilus surinamensis, } \\
\text { Sitophilus granarius, and } \\
\text { Tribolium castaneum }\end{array}$ & $\begin{array}{l}\text { Bioassay in laboratory } \\
\text { conditions }\end{array}$ & $\begin{array}{l}\text { Commercially produced, } \\
\text { formulated conidia of } \\
\text { B. bassiana strain PPRI } \\
5339 \text { (BbWeevil }^{\mathrm{TM}} \text {, } \\
\text { Biological Control } \\
\text { Products, South Africa) } \\
\text { containing } 2.9 \times 10^{9} \\
\text { conidia per gram of } \\
\text { powder was used, } \\
\text { Formulation was } \\
\text { applied at five rates of: } \\
0,250,500,750 \\
\text { and } 1000 \mathrm{mg}^{-1} \text {. }\end{array}$ & $\begin{array}{l}\text { Khashaveh } \\
\text { et al. (2011) }\end{array}$ \\
\hline
\end{tabular}


Table 1 Summary of the control programs that successfully used Beauveria bassiana for crop protection from 2009 to 2019 (Continued)

\begin{tabular}{|c|c|c|c|c|c|c|}
\hline Continent & Country or region & $\begin{array}{l}\text { Application } \\
\text { strategy (alone } \\
\text { or combined } \\
\text { with other } \\
\text { biocontrol } \\
\text { agents) }\end{array}$ & Target pest & $\begin{array}{l}\text { Crops / bio- } \\
\text { assay condition }\end{array}$ & Inoculation Method & Authors \\
\hline & & & & & $\begin{array}{l}\text { Fifteen lots of } 1 \mathrm{~kg} \\
\text { of wheat grain } \\
\text { (one lot for each } \\
\text { exposure time-rate) } \\
\text { were prepared and placed } \\
\text { in separate cylindrical jars } \\
\text { ( } 2 \text { l capacity with screwed lids) } \\
\text { and treated with the } \\
\text { appropriate dose }\end{array}$ & \\
\hline Asia & Iran & Alone & $\begin{array}{l}\text { Adults of } \\
\text { Callosobruchus } \\
\text { maculatus (F.) and } \\
\text { Sitophilus granarius (L.) }\end{array}$ & $\begin{array}{l}\text { Bioassay in laboratory } \\
\text { using stored grain } \\
\text { of wheat and cowpea }\end{array}$ & $\begin{array}{l}\text { Adults were tested } \\
\text { with five } 0,250,500, \\
750 \text { and } 1000 \mathrm{mg}^{-1} \mathrm{~kg}^{-1} \\
\text { and exposure intervals } \\
\text { of } 5,10 \text { and } 15 \text { days, } \\
\text { in }(24 \pm 2)^{\circ} \mathrm{C} \text { and } \\
(50 \pm 5) \% \\
\text { relative humidity }\end{array}$ & $\begin{array}{l}\text { Khashaveh } \\
\text { et al. (2011) }\end{array}$ \\
\hline \multirow[t]{2}{*}{ Asia } & \multirow[t]{2}{*}{ Jordan } & \multirow{2}{*}{$\begin{array}{l}\text { Combined } \\
\text { with neem } \\
\text { (Azadirachta } \\
\text { indica) tree } \\
\text { extract }\end{array}$} & \multirow{2}{*}{$\begin{array}{l}\text { Thrips tabaci } \\
\text { Lindeman (1889) } \\
\text { (Thysanoptera: } \\
\text { Thripidae) }\end{array}$} & \multirow[t]{2}{*}{$\begin{array}{l}\text { Potted tomato plants } \\
\text { in a greenhouse }\end{array}$} & $\begin{array}{l}\text {-Topical application } \\
\text { of a mixture of the } \\
\text { two control agents }\end{array}$ & \multirow[t]{2}{*}{$\begin{array}{l}\text { Al-mazra'awi } \\
\text { et al. (2009) }\end{array}$} \\
\hline & & & & & $\begin{array}{l}\text {-Topical application } \\
\text { of } B \text {. bassiana and a } \\
\text { drenching application } \\
\text { of neem tree extract }\end{array}$ & \\
\hline $\begin{array}{l}\text { Europe } \\
\text { and Asia }\end{array}$ & Turkey & Alone & $\begin{array}{l}\text { June beetle, Polyphylla } \\
\text { fullo (L.) (Coleoptera: } \\
\text { Scarabaeidae) }\end{array}$ & $\begin{array}{l}\text { Bioassay in laboratory } \\
\text { conditions }\end{array}$ & $\begin{array}{l}\text {-B. bassiana strain PPRI } \\
5339 \text {,product }\left(\mathrm{min}^{-1}\right. \\
4 \times 10^{9} \text { conidia. } \mathrm{mL}^{-1} \text { ) was } \\
\text { applied at } 100,150 \\
\text { and } 200 \mathrm{~mL} \text { per } 100 \mathrm{~L} \text { water }\end{array}$ & $\begin{array}{l}\text { Erler and Ates } \\
\text { (2015) }\end{array}$ \\
\hline Europe & Bulgaria & Alone & $\begin{array}{l}\text { Tetranychus urticae } \\
\text { Koch.(Acari:Tetranychidae) }\end{array}$ & Laboratory conditions & $\begin{array}{l}\text { treated by spraying } \\
\text { conidial suspensions } \\
\text { of isolates at } \\
\text { concentrations of } 10^{6} \\
10^{7} \text { and } 10^{8} \text { conidia/ml. } \\
\text { Lethal }\end{array}$ & $\begin{array}{l}\text { Draganova and } \\
\text { Simova (2010) }\end{array}$ \\
\hline Europe & Central Europe & Alone & $\begin{array}{l}\text { Ips typographus, } \\
\text { spruce bark beetle }\end{array}$ & Spruce & Tested by direct contact & $\begin{array}{l}\text { Mudrončeková } \\
\text { et al. (2013) }\end{array}$ \\
\hline Europe & France & Alone & $\begin{array}{l}\text { The pollen beetles ( } \\
\text { Meligethes spp.) }\end{array}$ & $\begin{array}{l}\text { Bioassay in laboratory } \\
\text { conditions }\end{array}$ & $\begin{array}{l}\text { Spraying of an oil } \\
\text { formulation of } \\
\text { Beauveria bassiana }\end{array}$ & Kaiser et al. (2016) \\
\hline \multirow[t]{2}{*}{ Europe } & \multirow[t]{2}{*}{ Germany } & \multirow[t]{2}{*}{ Alone } & $\begin{array}{l}\text {-vine mealybug ( } \\
\text { Planococcus ficus) }\end{array}$ & \multirow{2}{*}{$\begin{array}{l}\text { Bioassay in } \\
\text { greenhouse and field } \\
\text { experiments with } \\
\text { grapevine Vitis } \\
\text { vinifera (L.) }\end{array}$} & \multirow{2}{*}{$\begin{array}{l}\text { Applied either as } \\
\text { conidial suspensions } \\
\text { (ATCC } 74040 \text { and GHA) } \\
\text { or as a formulated } \\
\text { product (Naturalis', } \\
\text { strain ATCC 74040) on } \\
\text { grapevine leaves. }\end{array}$} & \multirow[t]{2}{*}{$\begin{array}{l}\text { Rondot and } \\
\text { Reineke (2018) }\end{array}$} \\
\hline & & & $\begin{array}{l}\text { - grape leafhopper } \\
\text { (Empoasca vitis) }\end{array}$ & & & \\
\hline Europe & Hungary & Alone & $\begin{array}{l}\text { Tetranychus urticae (Koch) } \\
\text { (Acarina: Tetranychidae). }\end{array}$ & $\begin{array}{l}\text { Bioassay in laboratory } \\
\text { conditions }\end{array}$ & $\begin{array}{l}\text { Applying at } 10^{4}, 10^{5} \\
10^{6}, 10^{7}, 10^{8}, 10^{9} \text { and } \\
3.7 \times 10^{9} \text { conidia } \mathrm{mL}^{-1}\end{array}$ & Yeșılayer (2018) \\
\hline Europe & Romania & Alone & $\begin{array}{l}\text { Beet armyworm ( } \\
\text { Spodoptera exigua) } \\
\text { (Lepidoptera: Noctuidae) }\end{array}$ & $\begin{array}{l}\text { Bioassay in laboratory } \\
\text { conditions }\end{array}$ & $\begin{array}{l}2 \mathrm{~g} / \mathrm{L} \text { water } \\
\text { concentration of } \\
\text { B. bassiana }\end{array}$ & $\begin{array}{l}\text { Hasyim et al. } \\
\text { (2017) }\end{array}$ \\
\hline Europe & UK & $\begin{array}{l}\text { Combined } \\
\text { with predator } \\
\text { Phytoseiulus }\end{array}$ & $\begin{array}{l}\text { Tetranychus urticae } \\
\text { Koch (Acari: Tetranychidae) }\end{array}$ & Bean plants & $\begin{array}{l}\text { single application of } \\
\text { B. bassiana }\left(1 \times 10^{8}\right. \\
\text { spore per } \mathrm{mL}) \text { after }\end{array}$ & $\begin{array}{l}\text { Ullah and Lim } \\
\text { (2017) }\end{array}$ \\
\hline
\end{tabular}


Table 1 Summary of the control programs that successfully used Beauveria bassiana for crop protection from 2009 to 2019 (Continued)

\begin{tabular}{|c|c|c|c|c|c|c|}
\hline Continent & Country or region & $\begin{array}{l}\text { Application } \\
\text { strategy (alone } \\
\text { or combined } \\
\text { with other } \\
\text { biocontrol } \\
\text { agents) }\end{array}$ & Target pest & $\begin{array}{l}\text { Crops / bio- } \\
\text { assay condition }\end{array}$ & Inoculation Method & Authors \\
\hline & & $\begin{array}{l}\text { persimilis } \\
\text { (Acari: } \\
\text { Phytoseidae) }\end{array}$ & & & $\begin{array}{l}\text { application of the } \\
\text { low release rate } \\
\text { of } P \text {. persimilis } \\
\text { ( } 5 \text { prey: } 1 \text { predator) }\end{array}$ & \\
\hline Oceania & Australia & Alone & $\begin{array}{l}\text { Aphis gossypii and } \\
\text { Chortoicetes terminifera }\end{array}$ & $\begin{array}{l}\text { Cotton, wheat, corn, } \\
\text { pumpkin, bean, } \\
\text { tomato }\end{array}$ & $\begin{array}{l}\text { Feeding larvae } \\
\text { using leaves } \\
\text { colonized by the } \\
\text { entomopathogens } \\
\text { B. bassiana }\end{array}$ & $\begin{array}{l}\text { Gurulingappa et al. } \\
\text { (2010). }\end{array}$ \\
\hline Oceania & New Zealand & Alone & $\begin{array}{l}\text { Bark beetle pests } \\
\text { of plantation forest } \\
\text { trees }\end{array}$ & Radiata pine & $\begin{array}{l}\text { Inoculation of } \\
\text { seed and seedlings }\end{array}$ & $\begin{array}{l}\text { Brownbridge et al. } \\
\text { (2012) }\end{array}$ \\
\hline
\end{tabular}

entomopathogenic nematodes and microorganisms in order to identify the factors that determine compatibility and synergy between the various biocontrol agents for their use in the biological control programs including $B$. bassiana.

\section{Difficulties related to the formulation of biopesticide based on B. bassiana}

Formulation is the conditoning of the biopesticide in a commercial form (mixture useable in the dry state or dispersed in water for spraying). According to Jones \& Burges (1998) reported by Leggett et al. (2011), formulation of biocontrol agents can be used to: stabilize the organisms during production, distribution and storage; facilitate the handling and application of the product; protect the agent from harmful environmental factors; and enhance the activity of the organisms. From this definition, it appears that the goal of formulating biopesticides is to make these technologies more predictable and competitive comparable to synthetic pesticides:

- Facilitate dispersion, manipulation;

- Make the dosage more precise (measurement);

- Add interesting properties (dispersion, adhesion, protection against UV, against desiccation, penetration ...);

- Improve storage stability (keep these properties at best for 24 months);

- Finally, a biopesticide protects better the environment than chemical pesticide.

The difficulties related to the formulation of the biopesticide based on $B$. bassiana include finding materials to be combined, to get not only the viability of conidia but also their stability (eg. desiccation tolerance, UV protection, shelf life, etc.) and their effectiveness.
The granulated formulations can be obtained either by coating previously harvested spores (Leland and Behle 2005; Sabbahi 2008) or by growth and sporulation of the fungus on the surface of a granular nutrient carrier. The first method, already applied to many auxiliary microorganisms, easily industrialized, is still insufficiently tested in the field for entomopathogenic fungi and prospects for agronomical use cannot be accurately estimated (Sabbahi 2008). Oily formulations containing UV, humectant and nutrient protectors for spore germination and growth have great potential for better results (Bateman et al. 1994; Burges 1998; Goettel et al. 1990). In this point of view, Todorova and Weill (2006) showed in a field trial against the Colorado potato beetles that the oil had been added to prevent desiccation of conidia and milk for protection of very harmful UV rays for B. bassiana. Oils also provide better adhesion and adequate spore application to the hydrophobic cuticle and insect (Douro et al. 2012a, b). For example, Croda's technical expertise covers a range of technologies and processes for advanced additives and adjuvants. Through Croda's approach, the best approach to choose a formulation adjuvant is to use mild and biocompatible surfactants such as: low risk nonionic polymers, sorbitan esters and polysorbates.

\section{Biopesticides market in Africa}

Companies that obtained patents

The biopesticide market is still in its early stage of development because the rate of biopesticides sold versus chemical pesticides is only $0.25 \%$ (van Lenteren 2000 cited by Caron (2006)). Several reasons can explain the fragility of this market:

- Product approval procedures may take time.

- Lack of study on assessing or establishing evident profitability for the producer and the consumer in 
comparison to chemicals. For example, the treatment cost of $B$. bassiana is not yet established. The treatment cost depends on the product price, the treatment frequency and labour for treatment (Sabbahi 2008)

- Most biopesticides consisted of living organisms often with relatively narrow spectrum of target pests and their effectiveness depends on environmental factors (Caron 2006).

Some of the companies that have obtained patents include: Biological Control Products SA (Pty) Ltd., BASF South Africa (Pty) Ltd., Plant Health Products (Pty) Ltd., Dudutech (Pty) Ltd. involved in the production and sale of biologically based products for agriculture in Africa and other part of the world.

\section{Commercialized products}

Information are given in Table 2 on commercialized products of manufacturers in Africa.

\section{Attempting on the use of $B$. bassiana in cotton Lepidopteran pest management}

Cotton as the first cash crop in Benin is incomegenerating for all links in the value chain. It contributes $80 \%$ to official export earnings and 13\% to GDP (Afouda et al. 2013). In 2018-2019 season, the recorded production was $700000 \mathrm{t}$, ranking Benin as the largest producer in West Africa (Tonavoh 2019). The increase in cotton production is related to the expansion of cultivated areas, the use of new cotton varieties (CRA-CF 2018). Expansion of cultivated area led to higher consumption of chemical pesticides in order to overcome insect pests damage (Westerberg 2017). Indeed, cotton is the most damaged crop in Benin. Over than 500 species have been reported attacking cotton plants (Celini 2001). In Benin, almost $90 \%$ of all imported pesticides are applied on cotton to control the various insect pests. This led to an overuse of chemicals with many side effects such as human hazards (frequent pesticide poisoning, skin and stomach irritation), insect pest resurgence and resistance, environmental pollution (Lawani et al. 2017). Insect resistance mainly of Lepidopteran species is major issue to be solved for boosting cotton production in Benin. The major Lepidopteran insect pests of cotton in Benin are carpophagous and phyllophagous caterpillars namely $H$. armigera, Pectinophora gossypiella, Syllepte derogata and Diparopsis watersi. Many studies have reported the resistance of $H$. armigera to synthetic pyrethroids as worldwide problem in Australia, China, India, Spain, Ivory-Coast and Benin (Martin et al. 2000; Djihinto et al. 2009; Brun-Barale et al. 2010). Managing these pests is a big challenge in the context of resistance (Djihinto et al. 2016). The most frequently used active substances were insecticides such as acetamiprid, lambda-cyhalothrin, chlorpyrifos-ethyl, emamectin benzoate, profenofos or cypermethrin; all are known to be more or less toxic and may have detrimental effects on heath after exposure (Gouda et al. 2018). Current management strategies to deal with insect resistance consisting of combining molecules having different modes of action or alternating insecticidal compounds with sequential applications do not always give expected level of control. Therefore, alternative environmental sound methods namely biological control using entomopathogenic organisms become an attractive option to manage especially resistance in Lepidopteran species. In this perspective, the entomopathogen $B$. bassiana is a promising candidate.

The current review addresses the great potential of $B$. bassiana for the control of several insect pest species. In Benin, more than 20 isolates of $B$. bassiana were stored at the entomopathogen bank of the International Institute of Tropical Agriculture (IITA) Benin station. Of these, only two isolates were tested on cotton Lepidopteran species namely $H$. armigera (Douro et al. 2012a, b). This study demonstrated that direct spray of the fungal suspension was effective against $H$. armigera inducing high mortality in larvae. There is a great need of information on the potential of $B$. bassiana to control cotton Lepidopteran species in the context of their resistance against the currently applied synthetic chemicals. Assessing the susceptibility of the main caterpillars destroying cotton plants to the different isolates, determining the lethal doses of virulent isolates are important steps in developing effective strategy of B. bassiana application in cotton production. Besides the effect of direct application of $B$. bassiana suspension on cotton Lepidopteran caterpillars, the endophytic colonization of cotton plant by $B$. bassiana may influence the survival of caterpillars feeding on different plant organs. Indeed, cotton is one of the plant species that can be colonized by the endophyte B. bassiana (Griffin 2007; Gurulingappa et al. 2010). This fungus species is known to colonize plant tissues giving a natural defense against different pests through various synthesized metabolites without being harmful to colonized plants. Assessing the effect of such colonization on cotton Lepidopteran species would be useful in defining effective control strategy in the context of insect resistance to chemicals. Laboratory studies should be supported by field experiments to find optimal use of $B$. bassiana in cotton production. The optimization of the use of $B$. bassiana through direct application or endophytic colonization of cotton plant would contribute to reducing control cost for a sustainable cotton production. Increase in cotton production would improve farmers' income and thereby food security in rural areas of Benin. 
Table 2 Presentation of manufacturers in Africa and commercialized products

\begin{tabular}{|c|c|c|c|c|c|}
\hline Manufacturer & Registration & Products & $\begin{array}{l}\text { Name of } \\
\text { products }\end{array}$ & Brief description of products & $\begin{array}{l}\text { Role/Disease or target } \\
\text { pest controlling }\end{array}$ \\
\hline \multirow[t]{2}{*}{$\begin{array}{l}\text { Plant Health } \\
\text { Products (Pty) Ltd. }\end{array}$} & \multirow[t]{2}{*}{$\begin{array}{l}\text { South } \\
\text { Africa }\end{array}$} & \multirow[t]{2}{*}{$\begin{array}{l}\text { Biofungicide \& } \\
\text { Biostimulant }\end{array}$} & \multirow[t]{2}{*}{ ECO-T } & \multirow[t]{2}{*}{$\begin{array}{l}\text { Contains Trichoderma } \\
\text { asperellum (previously } \\
\text { known as T. harzianum) }\end{array}$} & $\begin{array}{l}\text { - Management of } \\
\text { common root } \\
\text { diseases including } \\
\text { Fusarium, Rhizoctonia, } \\
\text { Pythium and } \\
\text { Phytophthora }\end{array}$ \\
\hline & & & & & $\begin{array}{l}\text {-Eco-T stimulates plant } \\
\text { root growth, improves } \\
\text { germination offering faster } \\
\text { seedling development and } \\
\text { promotes healthier, more } \\
\text { productive plants }\end{array}$ \\
\hline \multirow[t]{2}{*}{$\begin{array}{l}\text { Plant Health } \\
\text { Products (Pty) Ltd. }\end{array}$} & \multirow[t]{2}{*}{$\begin{array}{l}\text { South } \\
\text { Africa }\end{array}$} & \multirow[t]{2}{*}{$\begin{array}{l}\text { Biofungicide \& } \\
\text { Biostimulant }\end{array}$} & \multirow[t]{2}{*}{ Eco-T Ezi-Flo } & \multirow[t]{2}{*}{$\begin{array}{l}\text { Eco-T in a graphite/talc } \\
\text { lubricant formulation, } \\
\text { suitable for use with } \\
\text { mechanical planters } \\
\text { (Eco-T Ezi-Flo) }\end{array}$} & $\begin{array}{l}\text { Management of common } \\
\text { root diseases including } \\
\text { Fusarium, Rhizoctonia, } \\
\text { Pythium and Phytophthora }\end{array}$ \\
\hline & & & & & $\begin{array}{l}\text {-Eco-T stimulates plant root } \\
\text { growth, improves germination } \\
\text { offering faster seedling } \\
\text { development and promotes } \\
\text { healthier, more productive } \\
\text { plants }\end{array}$ \\
\hline \multirow[t]{2}{*}{$\begin{array}{l}\text { Plant Health } \\
\text { Products (Pty) Ltd. }\end{array}$} & \multirow[t]{2}{*}{$\begin{array}{l}\text { South } \\
\text { Africa }\end{array}$} & \multirow[t]{2}{*}{ Aerial Biofungicide } & \multirow[t]{2}{*}{ Eco-77 (T-77) } & Aerial biofungicide & $\begin{array}{l}\text {-Effective against Botrytis on } \\
\text { leaves, flowers and fruit for } \\
\text { cucumbers and tomatoes } \\
\text { and grapevine }\end{array}$ \\
\hline & & & & $\begin{array}{l}\text { Eco-77 is a wettable } \\
\text { powder (WP) concentrate } \\
\text { of a beneficial aerial } \\
\text { Trichoderma atroviride } \\
\text { (previously known as }\end{array}$ & $\begin{array}{l}\text { - Eco-77 colonizes pruning } \\
\text { wounds and prevents } \\
\text { pathogens like Botrytis } \\
\text { from gaining entrance to } \\
\text { the vineyard }\end{array}$ \\
\hline
\end{tabular}

\section{Plant Health South Bio-insecticide}

Products (Pty) Ltd. Africa

Plant Health South

Products (Pty) Ltd. Africa

Biological Control South Products SA (Pty) Ltd Africa

\section{-Bio fertilizers}

- Soil inoculants

-Plant stimulants

- Bio-pesticides
Eco-Bb (Bb-Protec)

Eco-Bb infects and kills whitefly, spider mite, Fall armyworm (Spodoptera frugiperda), False codling moth Thaumatotibia (Cryptophlebia leucotreta), Tuta absoluta and various other agricultural insect pests

Their bacterial inoculant improve fixing nitrogen in the root nodules of soya bean (soybean) and Lucerne (Alfalfa)

-bio fertilizers that help in keeping and sustaining the biological population in soil, as well as aid in the nutrient management of plants

- soil inoculants, which are a range of micro-organisms that build and replenish the biological population in soil

-plant stimulants, which are a range of products that assist plants through periods of stress, as well as optimize plant development during the critical growth stages 
Table 2 Presentation of manufacturers in Africa and commercialized products (Continued)

\begin{tabular}{|c|c|c|c|c|c|}
\hline Manufacturer & Registration & Products & $\begin{array}{l}\text { Name of } \\
\text { products }\end{array}$ & Brief description of products & $\begin{array}{l}\text { Role/Disease or target } \\
\text { pest controlling }\end{array}$ \\
\hline & & & & & $\begin{array}{l}\text {-and bio-pesticides that } \\
\text { control plant pests and } \\
\text { diseases }\end{array}$ \\
\hline $\begin{array}{l}\text { Biological Control } \\
\text { Products SA (Pty) Ltd }\end{array}$ & $\begin{array}{l}\text { South } \\
\text { Africa }\end{array}$ & Bio-pesticide & Bb Weevil & $\begin{array}{l}\text { CP formulation of Beauveria } \\
\text { bassiana conidia }\end{array}$ & $\begin{array}{l}\text { Used for the control of } \\
\text { Coleoptera (Curculionidae) }\end{array}$ \\
\hline $\begin{array}{l}\text { Biological Control } \\
\text { Products SA (Pty) Ltd }\end{array}$ & $\begin{array}{l}\text { South } \\
\text { Africa }\end{array}$ & Bio-pesticide & $\mathrm{Bb}$ Plus & $\begin{array}{l}\text { WP formulation of Beauveria } \\
\text { bassiana conidia }\end{array}$ & $\begin{array}{l}\text { Used for the control of } \\
\text { Hemiptera (Aphididae), } \\
\text { Acari (Tetranychidae) }\end{array}$ \\
\hline $\begin{array}{l}\text { BASF South } \\
\text { Africa (Pty) Ltd }\end{array}$ & $\begin{array}{l}\text { South } \\
\text { Africa }\end{array}$ & $\begin{array}{l}\text { Less bio-pesticide } \\
\text { and more chemicals, } \\
\text { plastics and agricultural } \\
\text { products }\end{array}$ & BroadBand $^{\circledR}$ & $\begin{array}{l}\text { Emulsifiable spore } \\
\text { concentrate (EC) of } \\
\text { Beauveria bassiana strain } \\
\text { PPRI5339, BroadBand } \\
\text { contains } 4 \mathrm{e} 9 \mathrm{CFU} \cdot \mathrm{mL}^{-1} \text {. It a } \\
\text { fungal contact insecticide, } \\
\text { derived from a hardy African } \\
\text { strain, isolated } \\
\text { from the tortoise beetle and } \\
\text { active at all stages of the life } \\
\text { cycle of insects - eggs, larvae, } \\
\text { juveniles and adults. }\end{array}$ & $\begin{array}{l}\text { BroadBand } \text { - a fungal } \\
\text { contact insecticide for the } \\
\text { effective reduction of target } \\
\text { insects on crops including } \\
\text { Plutella xylostella, } \\
\text { Thaumatotibia leucotret, } \\
\text { Aonidiella aurantii, } \\
\text { Tetranychus urticae, } \\
\text { Phthorimaea } \\
\text { opercullella, stinkbug, thrips, } \\
\text { whiteflies. Its effectively } \\
\text { controls the potato tuber } \\
\text { moth (Phthorimaea } \\
\text { opercullella) on potatoes, } \\
\text { red spider mite (Tetranychus } \\
\text { urticae) and whitefly on } \\
\text { tomatoes and thrips on } \\
\text { onions }\end{array}$ \\
\hline \multirow[t]{2}{*}{ Dudutech Ltd. } & \multirow[t]{2}{*}{ Kenya } & \multirow[t]{2}{*}{ Beneficial fungi } & \multirow[t]{2}{*}{ Beauvitech ${ }^{\oplus P}$} & \multirow[t]{2}{*}{$\begin{array}{l}\text { A wettable powder (WP) } \\
\text { formulation containing } \\
\text { spores of Beauveria } \\
\text { bassiana strain J25 }\end{array}$} & $\begin{array}{l}\text { Target challenge: aphids, } \\
\text { coffee berry borer, } \\
\text { leafminers, mealybugs, } \\
\text { scale insects, thrips, } \\
\text { whiteflies }\end{array}$ \\
\hline & & & & & $\begin{array}{l}\text { Crop: coffee, flowers, } \\
\text { fruits, vegetable }\end{array}$ \\
\hline \multirow[t]{2}{*}{ Dudutech Ltd. } & \multirow[t]{2}{*}{ Kenya } & \multirow[t]{2}{*}{ Beneficial fungi } & \multirow[t]{2}{*}{ Lecatech ${ }^{\oplus} \mathrm{WP}$} & \multirow{2}{*}{$\begin{array}{l}\text { A biological insecticide } \\
\text { containing Lecanicillium } \\
\text { lecanii, a naturally occurring } \\
\text { entomopathogenic fungus } \\
\text { that is effective against } \\
\text { whiteflies }\end{array}$} & $\begin{array}{l}\text { Target challenge: aphids, } \\
\text { leafminers, mealybugs, } \\
\text { scale insects, thrips, } \\
\text { whiteflies }\end{array}$ \\
\hline & & & & & $\begin{array}{l}\text { Crop: coffee, Flowers, } \\
\text { Fruits, Vegetables }\end{array}$ \\
\hline \multirow[t]{2}{*}{ Dudutech Ltd. } & \multirow[t]{2}{*}{ Kenya } & \multirow[t]{2}{*}{ Beneficial fungi } & \multirow[t]{2}{*}{ Mytech ${ }^{\circledR} \mathrm{WP}$} & \multirow{2}{*}{$\begin{array}{l}\text { A biological nematicide } \\
\text { based on Paecilomyces } \\
\text { lilacinus a naturally } \\
\text { occurring nematophagous } \\
\text { fungus for control of plant } \\
\text { parasitic nematodes }\end{array}$} & $\begin{array}{l}\text { Target challenge: } \\
\text { enhanced root } \\
\text { development, plant } \\
\text { parasitic nematodes }\end{array}$ \\
\hline & & & & & $\begin{array}{l}\text { Crop: cereals, coffee, } \\
\text { flowers, fruits, ea, } \\
\text { vegetables }\end{array}$ \\
\hline \multirow[t]{2}{*}{ Dudutech Ltd. } & \multirow[t]{2}{*}{ Kenya } & \multirow[t]{2}{*}{ Beneficial fungi } & \multirow[t]{2}{*}{ Trichotech ${ }^{\circledast} \mathrm{WP}$} & \multirow[t]{2}{*}{$\begin{array}{l}\text { Contains spores of } \\
\text { Trichoderma asperellum } \\
\text { an antagonistic fungus } \\
\text { that is used globally for } \\
\text { control of soil borne } \\
\text { fungal diseases }\end{array}$} & $\begin{array}{l}\text { Target challenge: } \\
\text { Armillaria, Botrytis Blight, } \\
\text { Crown Gall, Fusarium, } \\
\text { Pythium, Rhizoctonia, } \\
\text { Root Rots, Sclerotinia, } \\
\text { Stem Cankers }\end{array}$ \\
\hline & & & & & $\begin{array}{l}\text { Crop: cereals, flowers, } \\
\text { fruits, tea, vegetables }\end{array}$ \\
\hline \multirow[t]{2}{*}{ Dudutech Ltd. } & \multirow[t]{2}{*}{ Kenya } & \multirow[t]{2}{*}{$\begin{array}{l}\text { Beneficial insects } \\
\text { and predators }\end{array}$} & \multirow[t]{2}{*}{ Amblytech $C^{\circledast}$} & \multirow[t]{2}{*}{$\begin{array}{l}\text { Contains Amblyseius } \\
\text { cucumeris a predatory } \\
\text { mite used for the } \\
\text { management of Thrips }\end{array}$} & $\begin{array}{l}\text { Target challenge: broad } \\
\text { mite, cyclamen mite, } \\
\text { red spider mite, thrips } \\
\text { larvae }\end{array}$ \\
\hline & & & & & $\begin{array}{l}\text { Crop: flowers, fruits, } \\
\text { tea, vegetables }\end{array}$ \\
\hline
\end{tabular}


Table 2 Presentation of manufacturers in Africa and commercialized products (Continued)

\begin{tabular}{|c|c|c|c|c|c|}
\hline Manufacturer & Registration & Products & $\begin{array}{l}\text { Name of } \\
\text { products }\end{array}$ & Brief description of products & $\begin{array}{l}\text { Role/Disease or target } \\
\text { pest controlling }\end{array}$ \\
\hline \multirow[t]{2}{*}{ Dudutech Ltd. } & \multirow[t]{2}{*}{ Kenya } & \multirow[t]{2}{*}{$\begin{array}{l}\text { Beneficial insects } \\
\text { and predators }\end{array}$} & \multirow[t]{2}{*}{ Amblytech $^{\oplus}$} & \multirow{2}{*}{$\begin{array}{l}\text { Contains Amblyseius } \\
\text { californicus, a predatory } \\
\text { mite used for the } \\
\text { management of red } \\
\text { spider mites }\end{array}$} & $\begin{array}{l}\text { Target challenge: red } \\
\text { spider mite }\end{array}$ \\
\hline & & & & & $\begin{array}{l}\text { Crop: flowers, tea, } \\
\text { vegetables }\end{array}$ \\
\hline \multirow[t]{2}{*}{ Dudutech Ltd. } & \multirow[t]{2}{*}{ Kenya } & \multirow{2}{*}{$\begin{array}{l}\text { Beneficial insects } \\
\text { and predators }\end{array}$} & \multirow[t]{2}{*}{ Diglytech ${ }^{\circledast}$} & \multirow{2}{*}{$\begin{array}{l}\text { Contains living Diglyphus } \\
\text { isae, a parasitic wasp that } \\
\text { is ectoparasitic i.e. develops } \\
\text { nearby, but outside the leaf } \\
\text { miner larvae }\end{array}$} & Target challenge: leafminers \\
\hline & & & & & Crop: flowers, vegetables \\
\hline \multirow[t]{2}{*}{ Dudutech Ltd. } & \multirow[t]{2}{*}{ Kenya } & \multirow[t]{2}{*}{$\begin{array}{l}\text { Beneficial insects } \\
\text { and predators }\end{array}$} & \multirow[t]{2}{*}{ Hypotech ${ }^{\oplus}$} & \multirow{2}{*}{$\begin{array}{l}\text { Contains the predatory mite } \\
\text { Hypoaspis miles used for the } \\
\text { management of thrips, fungus } \\
\text { gnats, leaf miner, sciarid flies } \\
\text { and shore flies }\end{array}$} & $\begin{array}{l}\text { Target challenge: bulb } \\
\text { mites, leafminers, sciarid } \\
\text { flies, thrips }\end{array}$ \\
\hline & & & & & Crop: flowers, vegetables \\
\hline \multirow[t]{2}{*}{ Dudutech Ltd. } & \multirow[t]{2}{*}{ Kenya } & \multirow[t]{2}{*}{$\begin{array}{l}\text { Beneficial insects } \\
\text { and predators }\end{array}$} & \multirow[t]{2}{*}{ Phytotech $^{\oplus}$} & \multirow{2}{*}{$\begin{array}{l}\text { Contains a predatory mite } \\
\text { Phytoseiulus persimilis } \\
\text { marketed for management } \\
\text { of the two-spotted mite } \\
\text { (Tetranychus urticae) }\end{array}$} & $\begin{array}{l}\text { Target challenge: red } \\
\text { spider mite, two spotted } \\
\text { mite }\end{array}$ \\
\hline & & & & & $\begin{array}{l}\text { Crop: flowers, fruits, } \\
\text { vegetables }\end{array}$ \\
\hline \multirow[t]{2}{*}{ Dudutech Ltd. } & \multirow[t]{2}{*}{ Kenya } & \multirow[t]{2}{*}{$\begin{array}{l}\text { Beneficial } \\
\text { nemetodes }\end{array}$} & \multirow[t]{2}{*}{ Nematech $\mathrm{S}^{\oplus \mathrm{SP}}$} & \multirow{2}{*}{$\begin{array}{l}\text { A biological insecticide } \\
\text { containing infective } \\
\text { juveniles of Steinernema } \\
\text { feltiae (isolate DDT-D2) } \\
\text { in an inert carrier }\end{array}$} & $\begin{array}{l}\text { Target challenge: } \\
\text { leafminers, sciarid flies, } \\
\text { thrips }\end{array}$ \\
\hline & & & & & Crop: flowers, vegetables \\
\hline \multirow[t]{2}{*}{ Dudutech Ltd. } & \multirow[t]{2}{*}{ Kenya } & \multirow[t]{2}{*}{$\begin{array}{l}\text { Beneficial } \\
\text { nemetodes }\end{array}$} & \multirow[t]{2}{*}{ Nematech $\mathrm{H}^{\oplus}$} & \multirow{2}{*}{$\begin{array}{l}\text { A biological insecticide } \\
\text { containing infective } \\
\text { juveniles of Heterorhabditis } \\
\text { bacteriophora } \\
\text { (isolate DDT- F27) in an inert } \\
\text { carrier }\end{array}$} & $\begin{array}{l}\text { Target challenge: caterpillars, } \\
\text { cutworms, leafminers }\end{array}$ \\
\hline & & & & & Crop: flowers, vegetables \\
\hline \multirow[t]{2}{*}{ Dudutech Ltd. } & \multirow[t]{2}{*}{ Kenya } & \multirow{2}{*}{$\begin{array}{l}\text { Beneficial } \\
\text { nemetodes }\end{array}$} & Slugtech ${ }^{\circledast} \mathrm{SP}$ & A biological molluscicide & Target challenge: slugs, snails \\
\hline & & & & $\begin{array}{l}\text { containing infective juveniles } \\
\text { of Phasmarhabditis hermaphrodita } \\
\text { (isolate DDT M1) in an inert carrier }\end{array}$ & Crop: flowers, vegetables \\
\hline Dudutech Ltd. & Kenya & Beneficial virus & Helitech & $\begin{array}{l}\text { Helicoverpa armigera } \\
\text { nucleopolyhedrovirus (HearSNPV) }\end{array}$ & $\begin{array}{l}\text { Target challenge: Helicoverpa } \\
\text { armigera }\end{array}$ \\
\hline & & & & $\begin{array}{l}\text { Isolated from nature in Kenya and } \\
\text { has not been genetically altered }\end{array}$ & Crop: vegetables \\
\hline Dudutech Ltd. & Kenya & Botanics & NEMguard $^{\circledR}$ & $\begin{array}{l}\text { A powerful polysulphide solution } \\
\text { for the management of plant }\end{array}$ & $\begin{array}{l}\text { Target challenge: plant } \mathrm{p} \\
\text { arasitic nematodes }\end{array}$ \\
\hline & & & & & $\begin{array}{l}\text { Crop: lowers, fruits, } \\
\text { vegetables }\end{array}$ \\
\hline Dudutech Ltd. & Kenya & Botanics & $\mathrm{NEMROC}^{\otimes}$ & Azadirachtin & $\begin{array}{l}\text { Target challenge: plant } \\
\text { parasitic nematodes }\end{array}$ \\
\hline & & & & & Crop: flowers, egetables \\
\hline Dudutech Ltd. & Kenya & $\begin{array}{l}\text { Traps and } \\
\text { pheromones }\end{array}$ & Delta Trap ${ }^{\oplus}$ & $\begin{array}{l}\text { Traps for control of flying insect } \\
\text { pests. These traps are cost-effective, } \\
\text { readily assembled traps, are easy to }\end{array}$ & $\begin{array}{l}\text { Target challenge: diamonback } \\
\text { moth, Duponchelia, false } \\
\text { coddling moth, Tuta absoluta }\end{array}$ \\
\hline & & & & for a quick infestation count & Crop: flowers, vegetables \\
\hline Dudutech Ltd. & Kenya & $\begin{array}{l}\text { Traps and } \\
\text { pheromones }\end{array}$ & Rolltech Trap ${ }^{\circledast}$ & $\begin{array}{l}\text { Traps for control of flying insect } \\
\text { pests. This product comes in Blue } \\
\text { or Yellow depending on the target }\end{array}$ & $\begin{array}{l}\text { Target challenge: aphids, } \\
\text { leafminers, sciarid flies, thrips, } \\
\text { whiteflies }\end{array}$ \\
\hline & & & & pests & Crop: flowers, egetables \\
\hline Dudutech Ltd. & Kenya & $\begin{array}{l}\text { Traps and } \\
\text { pheromones }\end{array}$ & $\begin{array}{l}\text {-Blue STICKTECH } \\
\text { Yellow STICKTECH }\end{array}$ & $\begin{array}{l}\text { Blue STICKTECH and Yellow } \\
\text { STICKTECH }{ }^{\circ} \text { cards are used as the }\end{array}$ & $\begin{array}{l}\text { Target challenge for Blue } \\
\text { sticktech: thrips }\end{array}$ \\
\hline & & & & and trap" t & Target challenge for Yellow \\
\hline
\end{tabular}


Table 2 Presentation of manufacturers in Africa and commercialized products (Continued)

\begin{tabular}{|c|c|c|c|c|c|}
\hline Manufacturer & Registration & Products & $\begin{array}{l}\text { Name of } \\
\text { products }\end{array}$ & Brief description of products & $\begin{array}{l}\text { Role/Disease or target } \\
\text { pest controlling }\end{array}$ \\
\hline & & & & control of flying insect pests & $\begin{array}{l}\text { sticktech: aphids, false } \\
\text { coddling moth, leafminers, } \\
\text { mealybugs, sciarid flies, } \\
\text { whiteflies }\end{array}$ \\
\hline & & & & & Crop: flowers, vegetables \\
\hline \multirow[t]{2}{*}{ Dudutech Ltd. } & \multirow[t]{2}{*}{ Kenya } & \multirow{2}{*}{$\begin{array}{l}\text { Traps and } \\
\text { pheromones }\end{array}$} & Duponchelia ${ }^{\circledast}$ & \multirow{2}{*}{$\begin{array}{l}\text { These lures are rubber strips } \\
\text { impregnated with a synthetic } \\
\text { replica of the Duponchelia } \\
\text { female pheromone }\end{array}$} & Target challenge: Duponchelia \\
\hline & & & (Pheromone) & & Crop: flowers, vegetables \\
\hline \multirow[t]{2}{*}{ Dudutech Ltd. } & \multirow[t]{2}{*}{ Kenya } & \multirow[t]{2}{*}{$\begin{array}{l}\text { Traps and } \\
\text { pheromones }\end{array}$} & Tuta Absoluta ${ }^{\circledast}$ & \multirow{2}{*}{$\begin{array}{l}\text { Rubber strip lures, } \\
\text { impregnated with a } \\
\text { synthetic replica of the } \\
\text { Tuta absoluta female } \\
\text { pheromone }\end{array}$} & $\begin{array}{l}\text { Target challenge: Tuta } \\
\text { absoluta }\end{array}$ \\
\hline & & & (Pheromone) & & Crop: vegetables \\
\hline \multirow[t]{2}{*}{ Dudutech Ltd. } & \multirow[t]{2}{*}{ Kenya } & \multirow{2}{*}{$\begin{array}{l}\text { Traps and } \\
\text { pheromones }\end{array}$} & Planococus $^{\oplus}$ & \multirow{2}{*}{$\begin{array}{l}\text { Mealybug lures are rubber } \\
\text { strips impregnated with a } \\
\text { synthetic replica of the } \\
\text { mealy bug female } \\
\text { pheromone }\end{array}$} & Target challenge: mealybugs \\
\hline & & & (Pheromone) & & Crop: flowers, vegetables \\
\hline
\end{tabular}

\section{Conclusions}

Crop pests' management by using natural enemies becomes possible on a large scale within a reasonable time due to advances in research, combining laboratory and field studies in an operational perspective. Integrated pest management strategies including the use of $B$. bassiana currently available and reviewed here, offer better alternative to control insect pests especially cotton insect pests.

The major challenge in cotton production is to biologically control the key Lepidopteran species in the context of their resistance to the chemicals currently applied. Facing this challenge, the use of the entomopathogenic $B$. bassiana as a biopesticide could be a good alternative for insect pest control, one of the main constraints of cotton production in Benin. It can be used to minimize the frequency with chemical pesticides in conventional cotton and provides a non-existent solution in organic cotton.

\section{Acknowledgements}

Not applicable.

Authors' contributions

All authors read, edited, and approved the final manuscript.

Funding

Not applicable.

\section{Availability of data and materials}

Not applicable. No datasets were generated or analyzed in this review paper.

Ethics approval and consent to participate

Not applicable.

\section{Consent for publication}

Not applicable.

\section{Competing interests}

The authors declare that they have no competing interests.

\section{Author details}

'Laboratory of Phytotechnic, Improvement and Protection of Plants, Faculty of Agronomy, University of Parakou, BP 123, Parakou, Benin. ${ }^{2}$ International Institute of Tropical Agriculture, 08 BP 0932 Tri Postal, Cotonou, Benin.

${ }^{3}$ Normal Higher School, National University of Sciences, Technology, Engineering and Mathematics of Abomey, Natitingou, Benin. ${ }^{4}$ Agricultural Research Center on Cotton Fiber, National Agricultural Research Institute, Bohicon, Benin. ${ }^{5}$ Faculty of Sciences and Techniques, National University of Sciences Technology, Engineering and Mathematics, Dassa-Zoumè, Benin.

${ }^{6}$ Agricultural Policy Analysis Program, Agricultural Research Center, National Agricultural Research Institute, Agonkanmey, Benin.

Received: 16 January 2020 Accepted: 12 July 2020

Published online: 30 August 2020

\section{References}

Afouda R, Ahlonsou R, Amoussouga TB, et al. The cotton sector weaves its web in Benin. AgriProfocus. 2013.

Alizadeh A, Samih MA, Khezri M, et al. Compatibility of Beauveria bassiana (Bals.) Vuill. with several pesticides. Int J Agric Biol. 2007;34:1-31.

Al-mazra'awi MS, Al-Abbadi A, Shatnawi MA, et al. Effect of application method on the interaction between Beauveria bassiana and neem tree extract when combined for Thrips tabaci (Thysanoptera: Thripidae) control. J Food Agric Environ. 2009; 7(2):869-73.

Almeida AMB, de Batista FA, Tavares FM, et al. Screening of Beauveria bassiana for the control of Cosmopolites sordidus (Germar, 1824) (Coleoptera: Curculionidae). Arch Biol Inst (São Paulo). 2009;76(3):489-93.

Althouse CM, Petersen BE, McEwen LC. Effects of young American kestrels (Falco sparvericus) exposed to Beauveria bassiana bioinsecticide. Bull Environ Contam Toxicol. 1997:59:507-12

Amutha M, Gulsar Banu J, Surulivelu T, et al. Effect of commonly used insecticides on the growth of white muscardine fungus, Beauveria bassiana under laboratory conditions. J Biopesticides. 2010;3(special issue):143-6.

Araujo JM, Marques EJ, Oliveira JV. Potential of Metarhizium anisopliae and Beauveria bassiana isolates and neem oil to control the aphid Lipaphis erysimi (Kalt.) (Hemiptera: Aphididae). Neotrop Entomol. 2009;38(4):520-5. https://doi. org/10.1590/S1519-566X2009000400014.

Barbercheck ME, Kaya HK. Competitive interactions between entomopathogenic nematodes and Beauveria bassiana (Deuteromycotina: Hyphomycetes) in 
soilborne larvae of Spodoptera exigua (Lepidoptera Noctuidae). Environ Entomol. 1991;20:707-12.

Bateman RP, Carey M, Moore D, et al. The enhanced infectivity of Metarhizium flavoviride in oil formulations at low humidities. Ann Appl Biol. 1994;122: 145-52.

Boucias DG, Pendland JC, Latge JP. Attachment of mycopathogens to cuticule: the initial event of mycosis in arthropod host. In: The fungal spore and disease initiation in plants and animals. Cole GT, Hoch HC, editors. New York: Plenum; 1991. p. 101-128.

Brownbridge M, Reay SD, Nelson TL, et al. Persistence of Beauveria bassiana (Ascomycota: Hypocreales) as an endophyte following inoculation of radiata pine seed and seedlings. Biol Control. 2012;61(3):194-200. https://doi.org/10. 1016/j.biocontrol.2012.01.002

Brun-Barale A, Héma O, Martin T, et al. Multiple P450 genes overexpressed in deltamethrin-resistant strains of Helicoverpa armigera. Pest Manag Sci. 2010; 66(8):900-9. https://doi.org/10.1002/ps.1960.

Burges HD. Formulation of mycoinsecticides. In: Burges HD, editor. Formulation of microbiol biopesticides: benefical microorganisms, nemaodes and seed treatments. Dordrecht: Kluwer Academic Publishers; 1998. p. 31-185.

Butt TM, Beckett A. Structural studies on the infection processes of entomogenous fungi. Montpellier: Proceedings of Colloquium for Invertebr. Pathol; 1994. p. 311-4.

Butt TM, Ibrahim BV, Clark SJ, et al. The germination behavior of Metarhizium anisopliae on the surface of aphid and flea beetle cuticles. Mycol Res. 1995; 99:945-50.

Cagán L, Švercel M. The influence of ultraviolet light on pathogenicity of entomopathogenic fungus Beauveria bassiana (Balsamo) Vuillemin to the European corn borer, Ostrinia nubilalis HBN. (Lepidoptera: Crambidae). J Cent Eur Agric. 2001;2(3/4):228-37.

Caron J. Research and development of biopesticides and natural pesticides with low toxicity for non-target organisms and environment friendly. Final reportentomology section, PARDE project \# 3333.52.02.01. Quebec: Ministry of Sustainable Development, Environment and Parks (MDDEP); 2006.

Celini L. The cotton aphid Aphis gossypii (Glover) and its parasite Aphelinus gossypii Timberlake in the Central African Republic. Insects. 2001;122:1-4.

De Kouassi M. The possibilities of microbiological control, VertigO. The Electronic Journal in Environmental Science Online. 2001; 2(2):1-18. https://doi.org/10. 4000/vertigo.4091.

De Oliveira CR, Neves JOMP. Compatibility of Beauveria bassiana with acaricides. Neotrop Entomol. 2004:33(3):1-7.

Dembilio Ó, Quesada-Moraga E, Santiago-Álvarez C, et al. Potential of an indigenous strain of the entomopathogenic fungus Beauveria bassiana as a biological control agent against the red palm weevil, Rhynchophorus ferrugineus. J Invertebr Pathol. 2010;104(3):214-21. https://doi.org/10.1016/j. jip.2010.04.006

Djihinto AC, Katary A, Prudent $P$, et al. Variation in resistance to Pyrethroids in Helicoverpa armigera from Benin Republic, West Africa. J Econ Entomol. 2009; 102(5):1928-34. https://doi.org/10.1603/029.102.0525.

Djihinto CO, Affokpon A, Dannon E, et al. Reduction of doses of cypermethrintriazophos and reasoned control in cotton cultivation in Benin. J Appl Biosci. 2016;98:9261-9. https://doi.org/10.4314/jab.v98i1.3.

Douro KO, Djegui DA, Glitho IA, et al. Sensitivity of Helicoverpa armigera (Hübner) (Lepidoptera: Noctuidea) to the entomopathogenic fungi, Metarhizium anisopliae and Beauveria bassiana in laboratory. ARPN J Agric Biol Sci. 2012a; 7:1007-15. https://hdl.handle.net/10568/80862

Douro KO, Djegui DA, Glitho IA, et al. Response of the larval stages of Helicoverpa armigera (Hübner) (Lepidoptera: Noctuidae) by the using of entomopathogenic fungi Metarhizium anisopliae and Beauveria bassiana. Biotechnol Agron Soc Environ. 2012b;16(3):283-93. https://hdl.handle.net/1 0568/80842.

Draganova S, Simova S. Susceptibility of Tetranychus urticae Koch. (Acari: Tetranychidae) to isolates of entomopathogenic fungus Beauveria bassiana. Pestic PhytoMed (Belgrade). 2010;25(1):51-7.

El-Sufty R, Awash SA, Al-Bgham S, et al. Pathogenicity of the fungus Beauveria bassiana (Bals.) Vuill to the red palm weevil, Rhynchophorus ferrugineus (Oilv.) (Col.: Curculionidae) under laboratory and field conditions. Egypt J Biol Pest Control. 2009;19(1):81-5

Erler F, Ates AO. Potential of two entomopathogenic fungi, Beauveria bassiana and Metarhizium anisopliae (Coleoptera: Scarabaeidae), as biological control agents against the june beetle. J Insect Sci. 2015;15(1):44-9. https://doi.org/ 10.1093/jisesa/iev029.
Fan X, Wang Y, Li X, et al. Compatibility of Beauveria bassiana with five pesticides and their cotoxicity to Bradysia odoriphaga. Chin J Biol Control. 2017;33(4): 496-503.

Fargues J, Ouedraogo A, Goettel MS, et al. Effects of temperature, humidity and inoculation method on susceptibility of Schistocerca gregaria to Metarhizium flavoviride. Biocontr Sci Technol. 1997;7:345-56.

Faria M, Wraight SP. Biological control of Bemisia with fungi. Crop Prot. 2001;20: 767-78.

Fernandes EKK, Rangel DEN, Braga GUL, et al. Tolerance of entomopathogenic fungi to ultraviolet radiation: a review on screening of strains and their formulation. Curr Genet. 2015;61(3):427-40.

Food and Agriculture Organization. International code of conduct for the distribution and use of pesticides, guidelines for prevention and management of pesticide resistance. Rome: FAO; 2012. p. 1-62.

Fréchette B, Ziani J, Cormier D, et al. Use of Beauveria bassiana against the plum curculio, Conotrachelus nenuphar, in apple orchards. Quebec: Mirabel Agrifood Research Center; 2009.

Gao Y, Reitz SR, Wang J, et al. Potential of a strain of the entomopathogenic fungus Beauveria bassiana (Hypocreales: Cordycipitaceae) as a biological control agent against western flower thrips, Frankliniella occidentalis (Thysanoptera: Thripidae). Biocontrol Sci Tech. 2012;22(4):491-5. https://doi. org/10.1080/09583157.2012.662478.

Goble TA, Dames JF, Hill MP, et al. Investigation of native isolates of entomopathogenic fungi for the biological control of three citrus pests. Biocontrol Sci Tech. 2011;21(10):1193-211. https://doi.org/10.1080/09583157. 2011.608907.

Goettel MS, Poprawski TJ, Vandenberg JD, et al. Safety to nontarget invertebrates of fungal biocontrol agents. In: Laird M, Lacey LA, Davidson EW, editors. Safety of microbial insecticides. Boca Raton: CRC Press; 1990. p. 209-32.

Gouda A-I, Toko I, Salami I, et al. Phytosanitary practices and level of pesticide exposure of cotton producers in Northern Benin. Cah Agric. 2018;27(6):65002. https://doi.org/10.1051/cagri/2018038 .

Griffin MR. Beauveria bassiana, a cotton endophyte with biocontrol activity against seedling disease. Knoxville, TN, USA: University of Tennessee; 2007.

Gurulingappa P, Sword GA, Murdoch G, et al. Colonization of crop plants by fungal entomopathogens and their effects on two insect pests when in planta. Biol Control. 2010;55(1):34-41. https://doi.org/10.1016/j.biocontrol. 2010.06.011

Hajeck AE, St-Leger RJ. Interactions between fungal pathogens and insect hosts. Annu Rev Entomol. 1994;39:293-322.

Halouane F. Basic research on the entomopathogen Beauveria bassiana (Bals.-Criv.) Vuill. (Ascomycota: Hypocreales): bioecology, production and application on Schistocerca gregaria (Forskål, 1775) and Locusta migratoria (Linné, 1758) (Orthoptera, Acrididae). 2008. http://hdl.handle.net/123456789/784 .

Hasyim A, Setiawati W, Jayanti $H$, et al. Identification and pathogenicity of entomopathogenic fungi for controlling the beet armyworm Spodoptera exigua (Lepidoptera: Noctuidae). AAB Bioflux. 2017;9(1):34-46.

Inglis GD, Goettel MS, Butt TM, et al. Use of hyphomycete fungi for managing insectpests. In: Butt TM, Jackson CW, Magan N, editors. Fungi as biological agents: progress, problems and potential, vol. 2001. Wallingford, UK: CABI Publishing; 2001. p. 23-69.

Inglis GD, Goettel MS, Johnson DL. Persistence of the entomopathogenic fungus Beauveria bassiana on phylloplanes of crested wheatgrass and alfalfa. Biol Control. 1993;3:258-70.

Inglis GD, Ivie TJ, Duke GM, et al. Influence of rain and conidial formulation on persistence of Beauveria bassiana on potato leaves and Colorado potato beetle larvae. Biol Control. 2000;18:55-64.

Inyang EN, Mccartney HA, Oyejola B, et al. Effect of formulation, application and rain on the persistence of the entomopathogenous fungus Metarhizium anisopliae on oilseed rape. Mycol Res. 2000;104:653-61.

Islam MT, Omar DB. Combined effect of Beauveria bassiana with neem on virulence of insect in case of two application approches. J Anim Plant Sci. 2012;22(1):77-82

Jaber LR, Ownley BH. Can we use entomopathogenic fungi as endophytes for dual biological control of insect pests and plant pathogens? Biol Control. 2018;116:36-45. https://doi.org/10.1016/j.biocontrol.2017.01.018

Jacobson RJ, Chandler D, Fenlon J, et al. Compatibility of Beauveria bassiana (Balsamo) Vuillemin with Amblyseius cucumeris Oudemans (Acarina: Phytoseiidae) to control Frankliniella occidentalis Pergande (Thysanoptera: Thripidae) on cucumber plants. Biocontrol Sci Tech. 2010;11(3):391-400. https://doi.org/10.1080/09583150120055808. 
Jamal Z. Application of Beauveria bassiana against Lygus lineolaris (palisot de beauvois) (Hemiptera: Miridae) in vineyards. Montreal: University of Quebec; 2008.

Jaronski ST. Ecological factors in the inundative use of fungal entomopathogens. Biocontrol. 2010;55:159-85.

Kaiser D, Bacher S, Grabenweger G. Biological control of pollen beetles with the entomopathogenic fungus Beauveria bassiana formulated in oil. Proceedings of the IOBC/WPRS Working Group "Microbial and Nematode Control of Invertebrate Pests", Riga, Latvia, 7-11 June 2015. IOBC/WPRS Bulletin. 2016; 113:37-40.

Kamal T, Sobita S, Apoorv. Effect of Beauveria bassiana against diamondback month (Plutella xylostella Linn.) on cabbage (Brassica oleracea var capitata). Environ Ecol. 2018;36(1A):232-6.

Karthikeyan A, Selvanarayanan V. In vitro efficacy of Beauveria bassiana (Bals.) Vuill. and Verticillium lecanii (Zimm.) viegas against selected insect pests of cotton. Recent Res Sci Technol. 2011;3(2):142-3.

Khashaveh A, Ghosta Y, Safaralizadeh MH, et al. The use of entomopathogenic fungus, Beauveria bassiana (Bals.) Vuill. in assays with storage grain beetles. J Agric Sci Technol. 2011;13:35-43.

Kudemepo CT, Osipitan AA, Popopla RA, et al. Control of flea beetle Podagrica spp. (Coleoptera: Chrysomelidae) with entomopathogenic fungus Beauveria bassiana (Balsamo) Vuillemin in okra (Abelmoschus esculentus) (L.) Moench. Munis Entomol Zool. 2018;13(1):79-90.

Lambert N. Biological control of pests: applicability in Quebec. Quebec: University of Sherbrooke; 2010.

Lawani RAN, Kelome NC, Agassounon D, et al. Effects of agricultural practices on the pollution of surface water in Benin Republic. Larhyss J. 2017;30:173-90.

Leggett M, Leland J, Kellar K, et al. Formulation of microbial biocontrol agents an industrial perspective. Can J Plant Pathol. 2011;33(2):101-7. https://doi. org/10.1080/07060661.2011.563050

Leland JE, Behle RW. Coating Beauveria bassiana with lignin for protection from solar radiation and effects on pathogenicity to Lygus lineolaris. Biocontr Sci Technol. 2005;15:309-20.

Lewis LC, Berry EC, Obrycki JJ, et al. Aptness insecticides (Bacillus thuringiensis and carbofuran) with endophytic Beauveria bassiana, in suppressing larval populations of the European corn borer. Agric Ecosyst Environ. 1996;57: 27-37.

Li ZZ, Li CR, Huang B, et al. Discovery and demonstration of the teleomorph of Beauveria bassiana (Bals.) Vuill., an important entomogenous fungus. Chin Sci Bull. 2001;46(9):751-3.

Lipa JJ. White muscardine (Beauveria sp.). In: Lipa JJ, editor. An outline of insect pathology. Warsaw: Foreign Sciences Publications. Dept NCSTEl; 1975. p. 139-42.

Lord JC. From Metchnikoff to Monsanto and beyond: the path of microbial control. J Invertebr Pathol. 2005:89:19-29.

Lorencetti GAT, Potrich M, Mazaro SM, et al. Beauveria bassiana Vuill. and Isaria sp. efficiency for Thaumastocoris peregrinus Carpintero \& Dellapé (Hemiptera: Thaumastocoridae). Ciencia Florestal. 2018; 28(1):403-11. https:// doi.org/10.5902/1980509831612.

Magalhaes BP, Lord JC, Wraight SP, et al. Pathogenicity of Beauveria bassiana and Zoophthora radicans to the coccinellid predators Coleomegilla maculata and Eriopis connexa. J Invertebr Pathol. 1988;52:471-3.

Martin T, Ochou GO, Hala-N'Klo F, et al. Pyrethroid resistance in the cotton bollworm, Helicoverpa armigera (Hübner), in West Africa. Pest Manag Sci. 2000;56(6):549-54. https://doi.org/10.1002/(SICI)1526-4998(200006)56:6<549:: AID-PS160>3.0.CO;2-Y.

Mascarin MG, Jaronski TS. The production and uses of Beauveria bassiana as a microbial insecticide. World J Microbiol Biotechnol. 2016;32(177):1-26.

McCoy C, Quintela ED, Faria M. Environmental persistence of entomopathogenic fungi. In: Baur ME, Fuxa JR, editors. Factors affecting the survival of entomopathogens. Baton Rouge: Louisiana State University Agricultural Center, Southern Cooperative Series, Bulletin; 2002.

Mudrončeková S, Mazáň M, Nemčovič M, et al. Entomopathogenic fungus species Beauveria bassiana (Bals.) and Metarhizium anisopliae (Metsch.) used as mycoinsecticide effective in biological control of Ips typographus (L.). J Microbiol Biotechnol Food Sci. 2013;2(6):2469-72.

National Research Council. Pesticide resistance: strategies and tactics for management. Washington, DC: National Academy Press; 1986.

Nboyine JA, Asante SK, Nutsugah SK, et al. Biological control of the larger grain borer, Prostephanus truncatus (Horn) in stored maize using the fungal pathogen, beauveria bassiana and the predator Teretrius nigrescens Lewis. J
Stored Prod Postharvest Res. 2015;6(4):30-7. https://doi.org/10.5897/ JSPPR2015

Noma T, Strickler K. Factors affecting Beauveria bassiana for control of Lygus bug (Hemiptera: Miridae) in alfalfa seed fields. J Agric Urban Entomol. 1999;16(4): 215-33.

Olatinwo R, Walters S, Strom B. Impact of Beauveria bassiana (Ascomycota: Hypocreales) on the small southern pine engraver (Coleoptera: Scolytidae) in a loblolly pine bolt assay. J Entomol Sci. 2018;53(2):180-91.

Ortiz-Urquiza A, Keyhani NO. Action on the surface: entomopathogenic fungi versus the insect cuticle. Insects. 2013;4:357-74. https://doi.org/10.3390/ insects4030357.

Parsa S, Ortiz V, Vega F. Establishing fungal entomopathogens as endophytes: towards endophytic biological control. J Vis Exp. 2013;1-5(74):e50360. https:// doi.org/10.3791/50360.

Posada F, Aime MC, Peterson SW, et al. Inoculation of coffee plants with the fungal entomopathogen Beauveria bassiana (Ascomycota: Hypocreales). Mycol Res. 2007;111(6):748-57.

Posada F, Vega FE. Establishment of the fungal entomopathogen Beauveria bassiana (Ascomycota: Hypocreales) as an endophyte in cocoa seedlings (Theobroma cacao). Mycologia. 2005;97(6):1195-200.

Posada F, Vega FE. Inoculation and colonization of coffee seedlings (Coffea arabica L.) with the fungal entomopathogen Beauveria bassiana (Ascomycota: Hypocreales). Mycoscience. 2006;47(5):284-9.

Purwar JP, Sachan GC. Compatibility of entomogenous fungus, Beauveria bassiana with commonly used insecticides. Pestology. 2005;29(7):25-31.

Roberts DW. Toxins of entomopathogenic fungi. In: Burges HD, editor. Microbial control of pest and plant diseases 1970-1980. New York: Academic Press; 1981. p. 441-65.

Rondot $Y$, Reineke A. Endophytic Beauveria bassiana in grapevine Vitis vinifera (L.) reduces infestation with piercing-sucking insects. Biol Control. 2018;116:82-9. https://doi.org/10.1016/j.biocontrol.2016.10.006.

Sabbahi R. Use of the entomopathogenic fungus Beauveria bassiana in a strategy of phytosanitary management of the main insect pests in strawberry plantations. Quebec, Canada: University of Quebec; 2008.

Sensagent. Online encyclopedia, dictionary Parisien. Paris: Sensagent; 2000-2016.

Sewify GH, Belal MH, Al-Awash SA. Use of the Entomopathogenic fungus, Beauveria bassiana for the biological control of the red palm weevil, Rhynchophorus ferrugineus Olivier. Egypt J Biol Pest Control. 2009:19(2):157-63.

Shams G, Safaralizadeh MH, Imani S, et al. A laboratory assessment of the potential of the entomopathogenic fungi Beauveria bassiana (Beauvarin ) to control Callosobruchus maculatus (F.) (Coleoptera: Bruchidae) and Sitophilus granarius (L.) (Coleoptera: Curculionidae). Afr J Microbiol Res. 2011;5(10): 1192-6.

Shields MS, Lingg AJ, Heimsch RC. Identification of a Penicillium urticae metabolite which inhibits Beauveria bassiana. J Invertebr Pathol. 1981;38(3): 374-7.

Smith RJ, Grula EA. Toxic components on the larval surface of the com earworm (Heliothis zea) and their effects on germination and growth of Beauveria bassiana. J Invertebr Pathol. 1982:39:15-22.

St Leger RJ, Butt TM, Staples R, et al. Production of appressoria by the entomopathogenic fungus Metarhizium anisopliae. Exp Mycol. 1989a;13: 274-88.

St Leger RJ, Butt TM, Staples R, et al. Production in vitro of a cuticle-degrading protease by the entomopathogenic fungus Metarhizium anisopliae. Exp Mycol. 1989b;13:253-62.

Sung JM, Lee J-O, Humber RA, et al. Cordyceps bassiana and production of stromata in vitro showing Beauveria anamorph in Korea. Mycobiology. 2006; 34(1):1-6.

Tefera T, Vidal S. Effect of inoculation method and plant growth medium on endophytic colonization of sorghum by the entomopathogenic fungus Beauveria bassiana. Bio-Control. 2009;54:663-9. https://doi.org/10.1007/ s10526-009-9216-y\#citeas

Teng C. Studies on the biology of Beauveria bassiana (Bals.) Vuill. With reference to microbial control of insect pests. Acta Bot Sin. 1962;10(3):210-32.

Todorova S, Weill A. Artisanal production and use of the micro-fungus Beauveria bassiana for the biological control of potato pests. Quebec: support program for the development of organic agriculture of the Ministry of Agriculture, Fisheries and Food. 2006.

Todorova SI, Coderre D, Duchesne RM, et al. Compatibility of Beauveria bassiana with selected fingicides an herbicides. Environ Entomol. 1998; 27(2):427-33. 
Toffa-Mehinto J, Atachi P, Kobi O, et al. Pathogenecity of entomopathogenic fungi Metarhizium anisopliae and Beauveria bassiana on larvae of the legume pod borer Maruca vitrata ( Lepidoptera: Crambidae ). ARPN J Agric Biol Sci. 2014:9(2):55-64.

Togbé $C E$, Zannou E, Gbèhounou $G$ et al. Field evaluation of the synergistic effects of neem oil with Beauveria bassiana (Hypocreales: Clavicipitaceae) and Bacillus thuringiensis var. kurstaki (Bacillales: Bacillaceae). International Journal of Tropical Insect Science. 2014; 34(4): 248-59. https://doi.org/10. 1017/S1742758414000447.

Tonavoh F. Benin, the leading producer of cotton in West Africa. https://news. orificegroup.net. Accessed 1 Jan 2020.

Ugine T. The effect of temperature and exposure to Beauveria bassiana on tarnished plant bug Lygus lineolaris (Heteroptera: Miridae) population dynamics, and the broader implications of treating insects with entomopathogenic fungi over a range of temperatures. Biol Control. 2011; 59(3):373-83. https://doi.org/10.1016/j.biocontrol.2011.08.004 .

Ullah MS, Lim UT. Synergism of Beauveria bassiana and Phytoseiulus persimilis in control of Tetranychus urticae on bean plants. Syst Appl Acarol. 2017;22(11): 1924-35. https://doi.org/10.11158/saa.22.11.11

Vigneshwaran V. Entamopathogenic fungi as biocontrol agents - a special focus on Beauveria bassiana and Hirsutella. https://www.slideshare.net/ VigneshWaran16/entamopathogenic-fungi-as-biocontrol-agents-a-specialfocus-on-beauveria-bassiana-and-hirsutella. Access 1 Dec 2019.

Vijayavani S, Reddy KRK, Murthy GBVN. Pathogenicity of Beauveria bassiana (Deuteromycotina: Euteromycotina: Hyphomycetes ) strains on Spodoptera litura (Fab.). J Biopesticides. 2009;2(2):205-7.

Vodouhe S, Kooyman C, Ahanche A, et al. Potential of Beauveria bassiana and Metarhizium anisopliae isolates from Benin to control Plutella xylostella $\mathrm{L}$. (Lepidoptera : Plutellidae). Crop Prot. 2009;28(2009):220-4. https://doi.org/10. 1016/j.cropro.2008.10.009.

Wang YX, Wang XR, Chen JY, et al. Screening for highly virulent Beauveria bassiana Walker strains against Dendrolimus punctatus. I South Agric. 2016; 47(5):662-6.

Weiser J. Beauveria Vuill. In: Nemoci H, editor. Insect diseases. Prag, Czech: Academic Press; 1972. p. 361-77.

Westerberg V. The economics of conventional and organic cotton production. A case study from the municipality of Banikoara, Benin. Report for the Economics of Land Degradation Initiative. 2017. p.36.

Wraight RJ, Roberts DW. Insect control effort with fungi. Dev Ind Microbiol. 1987; 28:77-87.

Wraight SP, Ramos ME, Avery PB, et al. Comparative virulence of Beauveria bassiana isolates against lepidopteran pests of vegetable crops. J Invertebr Pathol. 2010;103(3):186-99. https://doi.org/10.1016/j.jp.2010.01.001.

Wu S, Gao Y, Smagghe G, et al. Interactions between the entomopathogenic fungus Beauveria bassiana and the predatory mite Neoseiulus barkeri and biological control of their shared prey / host Frankliniella occidentalis. Biol Control. 2016;98:43-51. https://doi.org/10.1016/j.biocontrol.2016.04.001.

Wu S, Gao Y, Xu X, et al. Laboratory and greenhouse evaluation of a new entomopathogenic strain of Beauveria bassiana for control of the onion thrips Thrips tabaci. Biocontrol Sci Tech. 2013;23(7):794-802. https://doi.org/ 10.1080/09583157.2013.794896.

Wu S, Gao Y, Xu X, et al. Compatibility of Beauveria bassiana with Neoseiulus barkeri for control of Frankliniella occidentalis. J Integr Agric. 2015;14(1):98105. https://doi.org/10.1016/S2095-3119(13)60731-5.

Xu WJ, Yin WH, Zhang ZK, et al. Selection of high efficient Beauveria bassiana strains against Ostrinia furnacalis. J Jilin Agric Sci. 2011;36(4):41-4.

Yeșlayer A. Efficiency of two different entomopathogen fungi Beauveria bassiana and Purpureocillium lilacinum TR1 against Tetranychus urticae. Appl Ecol Environ Res. 2018;16(5):6077-86.

Zimmermann G. Review on safety of the entomopathogenic fungi Beauveria bassiana and Beauveria brongniartii. Biocontrol Sci Tech. 2007;17(6):553-96. https://doi.org/10.1080/09583150701309006.

Ready to submit your research? Choose BMC and benefit from:

- fast, convenient online submission

- thorough peer review by experienced researchers in your field

- rapid publication on acceptance

- support for research data, including large and complex data types

- gold Open Access which fosters wider collaboration and increased citations

- maximum visibility for your research: over $100 \mathrm{M}$ website views per year

At BMC, research is always in progress.

Learn more biomedcentral.com/submissions 